\title{
Calixto Bieito y los ClÁsicos: COHEREnCia Y EVOLUCIÓN DE UN DIRECTOR DE ESCENA
}

\author{
Mar Zubieta TABernero \\ Compañía Nacional de Teatro Clásico
}

Title: Calixto Bieito and the classics: coherence and evolution of a stage director.

\begin{abstract}
Bieito's stage direction is characterized by a series of features. This article analyzes the importance of internationality, the contemporary, the management of violence, the scenography and the music, the cinema, the symbols and the treatment of classical texts in the director's world.
\end{abstract}

Key words: Calixto Bieito. Classics in Bieito. The scenography. The violence. Cinema and simbols.

Como sucede habitualmente, será el impulso creativo del director quien marque las coordenadas generales de sus puestas en escena, estableciéndose así una forma usual de trabajar combinada con unos rasgos específicos determinados que caracterizarán su labor en cada montaje. Por lo que se refiere a Calixto Bieito es importante fijar las líneas fundamentales que unen y consolidan su trabajo ya que, al no desarrollarse en un único ámbito geográfico, su importancia puede correr un mayor riesgo de desdibujarse a pesar de ser uno de nuestros directores de escena más conocidos y reconocidos fuera de España. Aquí se ha procurado sintetizar los rasgos más importantes de su forma de dirigir atendiendo sobre todo a su actividad teatral y especialmente a la relacionada con los textos clásicos, ya que profundizar en su labor como director de ópera, aunque es un aspecto muy atrayente de su carrera, excedería los límites de este artículo. Parece, sin embargo, que una y otra actividad escénica (teatro y ópera) comparten líneas semejantes, y por ello se ha utilizado para fijarlas material proveniente de ambos campos, obtenido tanto de entrevistas en las que el propio director da cuenta de sus claves y de su forma de trabajar como de opiniones de periodistas, críticos 
e investigadores, agudos observadores y analistas de sus puestas en escena. ${ }^{\mathrm{I}}$ En cualquier caso y como punto de partida, considero que en este director coexisten dos rasgos fundamentales: coherencia a lo largo de su carrera y también una patente capacidad de evolucionar.

Con respecto a su trayectoria profesional y a su personal combinación de trabajo y criterio artístico, Bieito afirma: "En Suecia me decían que parezco de allí. La base es la constancia; genios hay muy pocos”.

\section{Un director de escena internacional}

Lo primero que me gustaría destacar es que Bieito se aproxima a la dirección de escena a través de una formación sólida, ${ }^{2}$ tanto general (puesto que es licenciado en Filología Hispánica e Historia del Arte) como específica, ya que igualmente cursa estudios de Interpretación y Dirección de Escena. Además está vinculada desde muy pronto a estancias fuera de España, ampliando estudios en el extranjero en disciplinas muy variadas y con grandes maestros cuando aún era muy joven. Con solo 29 años (I992), enlaza esta etapa de aprendizaje con una estancia junto a Lluis Pasqual en el Odeón de París y una larga gira por Sudamérica antes de empezar a montar sus propios espectáculos. Uno de los primeros (La verbena de la Paloma, de I 996) fue visto en Barcelona por el director del Festival de Edimburgo, que le invitó a mostrarlo allí en i 997, algo que fue un hecho fundamental en la carrera del director. La acogida que Edimburgo dio al joven director de 34 años supuso una consolidación internacional de su carrera y una invitación habitual a mostrar sus espectáculos fuera de España, como sucedió al año siguiente con La vida es sueño, que Bieito llevó a Edimburgo en 1998.

${ }^{\mathrm{I}} \mathrm{La}$ mayor parte de las referencias del artículo ha sido consultada on line (fundamentalmente prensa y videos) mientras que otra parte es inédita, por lo que ninguna de las dos lleva paginación.

${ }^{2}$ Iniciada con sus estudios en los jesuitas, a cuyo interés por el teatro dentro de la esfera educativa atribuye Bieito su temprana focalización hacia la escena, agradeciéndoles siempre las representaciones de los clásicos que vio aún muy joven y un especial sentido del humor que le ha acompañado siempre. 
Desde entonces el director no ha dejado de estrenar y representar en muchos países de Europa, Sudamérica y en distintas ciudades de Estados Unidos, tanto teatro como ópera. El panorama de autores, compañías, festivales y entidades públicas y privadas en las ciudades donde Bieito ha trabajado y se han producido sus espectáculos es quien mejor puede aclararnos su identidad como director de escena internacional, que se anunciaba desde sus primeros pasos en el mundo del teatro. Sus puestas en escena, tanto teatrales como operísticas o de zarzuela nos hablan de la creatividad y capacidad de un director que no se ha detenido en las fronteras intelectuales o geográficas al uso, sino que ha ido aceptando desafíos uno tras otro, con los resultados de aceptación y éxito que reflejan galardones y premios otorgados por diferentes países.

\section{Coproducción de sus montajes}

Otro fenómeno típico de este director (que amplifica y ahonda en su internacionalidad) es el montar sus espectáculos con varios coproductores, de los que, frecuentemente, uno o dos no son españoles. Esta circunstancia refleja perfectamente el interés que su trabajo suscita fuera de España, pero además con ello Bieito se ha venido asegurando estrenos en ciudades europeas y una gira extensa, que en muchos casos conlleva el hecho de que sus montajes se vean primero fuera y luego dentro de nuestro país. Durante varios años era típico que estrenara en Edimburgo, fuera luego a Londres y después al Romea de Barcelona y a otros teatros del Estado español. Así sucede con La vida es sueño (en el arco temporal 1998-2000), con Macbeth (estrenada en alemán en 200I, en el Festival de Salzburgo) y con Hamlet (estrenada en catalán en 2002 en el Romea, en castellano en el Festival de Almagro de ese año y en 2003 traducida al inglés para su estreno en el Barbican Theatre de Londres y en el Festival de Edimburgo). Hay bastantes muestras en su carrera de esta característica, presente en montajes como $L a$ ópera de cuatro cuartos de 2002 (coproducida por Focus, Grec 2002, Sala- 
manca 2002, Mc93 Bobigny de París y Teatro Cuyás, representada también en 2004 en el Festival del Ruhr, en castellano con subtitulos en alemán), o como Peer Gynt de 2006 (coproducido por el Romea, el Grec 2006 y el Festival internacional de Bergen en Noruega) hasta llegar a su Pepita Jiménez, que se estrena en 2012 en el bonaerense Teatro de La Plata y en los teatros del Canal de Madrid en 2013, cantada en inglés y coproducida por ambos teatros.

Desde entonces al momento presente, en que es director artístico residente del Theater Basel especializado en montajes operísticos, Calixto Bieito ha recorrido un camino largo y coherente, profundizando siempre en esa internacionalidad que le ha caracterizado desde los comienzos de su carrera como un rasgo distintivo. Nos lo confirma una mirada a su biografía, a la que recientemente se ha sumado la dirección artística del Teatro Arriaga de Bilbao en enero de 20i6, que programa desde 2017.

\section{Los actores y el trabajo de ensayos}

La dirección de escena de Bieito está basada en una profunda colaboración con los actores que representan sus montajes, tanto teatrales como de ópera, y espectáculos de etapas distintas de su carrera lo muestran así. Exige a todos sus intérpretes una gran entrega, intensidad y un entusiasmo profundo (Zubieta, 200r: 98-99), ${ }^{3}$ pero los corresponde con las suyas de igual manera, algo que ellos le reconocen también a él. Así lo hace Nuria Gallardo refiriéndose al montaje de La vida es sueño (2000), destacando del director su

${ }^{3}$ Cuando le preguntamos qué ha intentado conseguir de sus actores en La vida es sueño, Bieito afirma: "El teatro es actores y público, y nada más. Me considero un director que hace espectáculos para que el actor, que es el número uno, esté implicado hasta el alma. Es importante asumir sobre el escenario tres deberes: generosidad, libertad y pasión, y sólo los actores pueden hacerlo. Yo, como director, les dedico el mayor tiempo del total de horas que me ocupa la construcción de una obra y a cambio les pido esa generosidad y esa pasión, no tener miedo al ridículo y la mejor preparación posible en voz, dicción y cuerpo". Mar Zubieta, "Conversaciones con el director de La vida es sueño, Calixto Bieito", Cuadernos de Teatro Clásico, i s, José Ma Díez Borque (dr.), (200 I), pp. 97-ıо . 
enorme capacidad de trabajo, riesgo y generosidad (Zubieta, 20 I 5). ${ }^{4}$ Bieito ayuda a sus actores a construir su personaje con todo tipo de indicaciones, no solo gestuales, sino también de voz, psicológicas y emocionales, solicitándoles un trabajo que lo dibuje en todos sus aspectos, como apunta Gallardo con respecto a Rosaura:

Son muchas cosas al mismo tiempo, por eso hay que estar muy abierto y él, por su parte, está muy atento y apoya mucho. Da muchísima información con todo lo que dice, y lo que hay que ver es que no sea contradictoria. Es decir, que te pida algo psicológico del personaje no quiere decir que emocionalmente no estés absolutamente activo, y que además físicamente tengas que hacer un recorrido de lado a lado (Zubieta, 20 I s).

Este punto de partida, basado en la confianza y la complicidad, es fundamental para el director e insiste en él a lo largo del tiempo, poniendo siempre de relieve la importancia del trabajo con los actores y con los cantantes (intérpretes, los llama él), siempre con un sentido de investigación y búsqueda, patente ya en sus primeros montajes como sucedía en Anfitrión ( 1996). Bieito quiere que la interpretación sea lo más natural posible, que se desprenda de clichés de artificiosidad expresiva o efectismos teatrales y que refleje la realidad actual, situándose en el ámbito lleno de prisas, rapidez y violencia que es el mundo de hoy para todos (Muñoz Rojas, I 996). ${ }^{5}$

Responde en un sentido parecido a las entrevistas que le hacen cuando estrena La tempestad (1997), hablando ahora de un "estilo de interpretación creíble, más cercano al cine [... y yuy violento, como todo lo que nos

${ }^{4} \mathrm{Al}$ hablar del tipo de dirección de actores que Bieito ejerce, de las indicaciones que les da y de la relación que mantiene con ellos, Nuria Gallardo comenta: "Para mí es una relación muy teatral y muy activa, muy de trabajo de personaje. [...] Es un director incombustible, y por eso él ya llega pensando en la escena; con él no puedes tener un tiempo muerto. Tú ya tienes que estar ahí, y desde ahí ponerte a volar, hacer lo que te pidan, dejarte: la entrega. Yo creo que él se entrega mucho y arriesga mucho cuando pide cosas". Mar Zubieta, "Entrevista a Nuria Gallardo", 20 I 5.

'Ritama Muñoz Rojas, "Creo que en Barcelona hay más apoyo de las instituciones al teatro”, entrevista a Calixto Bieito, El País, Madrid, 7/ I I/ i 996. 
rodea” (Muñoz Rojas, I 997). ${ }^{6}$ Podemos ver así que Bieito considera siempre la interpretación como la parte final de su proceso creador: para terminar el montaje el director precisa la colaboración de sus actores, e insiste en que busca personas creativas, libres y muy capaces, no seguidoras de unas instrucciones sino investigadores a su lado. Activos y responsables a lo largo de todo el proceso, esos son los actores con los que Bieito trabaja más cómodamente y los que elige para los repartos de sus montajes (Zubieta, 2016). ${ }^{7}$ Sus indicaciones escénicas son propuestas, caminos a seguir que todos, director y actores, andan juntos en una relación de confianza sustentada en los hallazgos del trabajo diario, que desarrolla unos planteamientos iniciales que nunca son imposiciones, sino líneas de viaje que dan alas al actor. Los planteamientos de Bieito son recursos a desplegar, básicamente estímulos que Gallardo llama "provocaciones", con una interacción que la actriz describe con detalle, colorido y aprecio puesto que guarda muy buenos recuerdos de su trabajo en La vida es sueño, (Zubieta, 20 I 5). ${ }^{8}$

Unos años más tarde, ya en 2005 y con ocasión del estreno de Wozzeck, la primera ópera contemporánea que dirige, Bieito ha elaborado más su personal forma de trabajar con los intérpretes, y la refiere de una manera mucho más amplia. Como reside fuera de España, son los institutos de

\footnotetext{
${ }^{6}$ Ritama Muñoz Rojas, "El premiado director Calixto Bieito trae su versión de La tempestad de Shakespeare”, El País Escena, 28/9/ 997.

${ }^{7}$ Mar Zubieta, "Segunda entrevista a Calixto Bieito, director de escena y autor de la versión de La vida es sueño", Bilbao, I4/4/2016.

${ }^{8}$ Gallardo nos lo comenta así: "MZ. - O sea que te daba imágenes, te daba recursos y te pedía. La confianza era mutua. NG.- Sí. Y pedía, pedía constantemente. No imponía imágenes, te pedía que buscaras imágenes, que pensaras cosas, que encontraras el camino para llegar hasta ahí. Nunca te daba un resultado, siempre te daba un proceso de trabajo. MZ.Eso está muy bien, y es porque cuenta con un tipo de actor creativo. NG.- Claro, eso es lo que necesita, fundamentalmente. Él te propone tirarte por la ventana y tú le dices que además saltarás en parapente. De eso es de lo que se trata, no de "¿Cómo voy a saltar por una ventana? ¡Dios mío, no!”. Claro, es una forma de hablar, se trata de decir: "Sí, y luego abro así las alas y entonces planeo". Y él te dice: "Vale. Hazlo". Calixto trabaja así. Él provoca para que tú vueles". Mar Zubieta, "Entrevista...", 20 I 5.
} 
artes escénicas y universidades alemanas quienes le solicitan que enseñe su método, dirigido ahora especialmente a cantantes, aunque también haya actores entre sus alumnos. A todos les pide una perspectiva contemporánea y, como ya venía haciendo tiempo atrás, que construyan sus personajes lejos de la afectación y de los clichés, anclados en el trabajo emocional y físico de los ensayos y por tanto apartados de estereotipos previos (Lourdes Morgades, 2005) $)^{9}$. Más recientemente (2012) pone en escena el espectáculo Forest, un collage textual en homenaje a Shakespeare con fragmentos de diferentes textos de este autor en torno a los árboles, el bosque y la Naturaleza y su relación con el ser humano, siempre buscando una línea poética. Bieito hace la dramaturgia del espectáculo junto a Marc Rosich, un traductor y dramaturgo que ya había colaborado con él en otras ocasiones y por tanto buen conocedor de sus métodos de trabajo. En esta ocasión el director impulsó un sistema que partía de un primer libreto donde no había referencias a personajes o trama sino solo texto, de manera que cada actor podía decir palabras correspondientes a diferentes personajes, pertenecientes a obras distintas de Shakespeare. La propuesta se fue matizando con el trabajo de los actores en los ensayos hasta llegar a conseguir un nuevo "texto completo", en donde los diferentes fragmentos cobraban un sentido que tenía que ver, tanto con

${ }^{9}$ Bieito describe así su "método de interpretación operística": "No sé si es un método. No me he sentado a escribirlo. Es una forma de trabajar que no sé si es ejemplar, pero es la mía y a la que he llegado por un proceso de negación, de descartar lo que no era. No es una técnica exclusiva para cantantes [...] No se trata de que hagan más o menos cosas. Hablo de cómo el cantante interpreta la música desde una óptica actual, a través de situaciones actuales y conflictos emocionales de hoy. Es una forma de trabajar fragmenta$\mathrm{da}$, en la que los personajes no son producto de un prototipo, sino la suma de una serie de situaciones, de conflictos y de tensiones vividas. Es un trabajo duro físicamente, pero normalmente funciona. Porque es cuando un espectáculo te toca, te traspasa, te desconcierta, cuando realmente te emociona". En Lourdes Morgades, "No estoy dispuesto a hacer ópera a cualquier precio", El País, 24/12/2005. 
la obra de Shakespeare de la que se había partido, como con el punto de llegada, el nuevo espectáculo que se ponía en escena (Marc Rosich, 20I 2). ${ }^{\circ}$

Resultado también de la internacionalidad de su carrera, Calixto Bieito ha trabajado a lo largo de ella con actores y cantantes de diferentes nacionalidades (especialmente españoles, ingleses y alemanes) sobre textos tanto en prosa como en verso, típicamente teatrales o bien provenientes del mundo de la ópera. Diferencia perfectamente las potencialidades de los distintos repartos, pero alude siempre a una forma de trabajo común con ellos que tiene que ver, como decíamos, con la confianza y con la complicidad profesional (Liz Perales, 2009). ${ }^{11}$ Con frecuencia investigadores y críticos refieren que estimula en sus actores una manera de decir el verso que tiene que ver con el impulso característico de los actores ingleses (Alejandro Cruz, 2010 $)^{12}$ de los que, efectivamente, Bieito considera que ha aprendido mucho, no solo porque los considera excelentes fónicamente sino porque le atrae su tradición escénica, que implica una manera suelta y vigorosa de

\footnotetext{
${ }^{10}$ Que revienten los artistas, Revista digital de Artes Escénicas, 4, "Entrevista a Marc Rosich", 5/I2/2012.

${ }^{1}$ Sobre si el trabajo con los actores es diferente dependiendo de su nacionalidad, Bieito afirma que: "Son materiales diferentes. Y la diferencia es la tradición y el concepto de compañía. Los alemanes tienen una tradición interpretativa muy expresionista, son teatros con compañías de repertorio y eso se nota. Hoy interpretan un obra y mañana otra distinta. La tradición inglesa también es muy poderosa, muy vinculada al texto. Y en España la tradición simplemente no existe, constantemente nos estamos preguntando cómo recitar el verso, algo impensable en una compañía inglesa. LP.- ¿Establece más complicidad con los actores alemanes o con los españoles? CB.- Los actores españoles tienen tanto o más talento que los alemanes. Y la complicidad depende de las personas. Yo a un actor siempre le pido complicidad profesional, quiero crear con él un espacio de disciplina e imaginación y si lo conseguimos, es muy gratificante". Liz Perales, "Sin arte ni espiritualidad la vida sería muy trivial”, entrevista a Calixto Bieito, El Cultural.es, 29/5/2009.

${ }^{12}$ Bieito comenta: "Aprendí con los actores británicos algo muy shakespeariano: que esto es un teatro alejado de la tradición romántica, de la tradición psicologista y del naturalismo. Aprendí que tiene que ver más con una especie de concierto, una especie de juego entre los actores y el público, y entre los mismos actores. Así me liberé del ritmo español, del verso", Alejandro Cruz, "Un triller filosófico del Siglo de Oro. Entrevista a Calixto Bieito", La Nación, Buenos Aires, I I/7/2010.
} 
hablar y, en general, una gran habilidad para crear con su forma de decir el texto la sensación de música y velocidad (Zubieta, 2016).

\section{Ser contemporáneo}

La contemporaneidad, lo contemporáneo, es un concepto que parece fundamental para Bieito, puesto que hace referencia a ello frecuentemente. ¿Qué significa ser contemporáneo para él? ¿Hablaríamos de este término en el sentido de que se ocupa en sus montajes del rabioso presente, de la actualidad "periodística", simplemente? O quizá podríamos ver que el concepto sirve más bien para transparentar una preocupación del director por la realidad más inmediata del ser humano y por sus consecuencias. Esta preocupación puede abarcar los sentimientos y las emociones o ser moral y transformarse en "política", orientando a lo social los temas que trata en sus puestas en escena y modulando el punto de vista desde el que nos los muestra, y también conducir los aspectos formales del montaje, matizando sus espectáculos. Esta es otra característica del director que le acompaña en toda su carrera: primero porque su trabajo lo muestra, y después porque él lo refiere así, de una manera u otra, a lo largo del tiempo. En 1996, por ejemplo, durante una entrevista con motivo del estreno de su Anfitrión en el teatro Lara de Madrid, Bieito deja apuntada su intención al dirigir, que consiste en trasladar al espectador su mirada sobre el mundo, opinando acerca de lo que ve (Muñoz Rojas, I996). ${ }^{13}$ En el caso de este texto de Plauto, que para nada el director consideraba una comedia, lo que le movió a escogerlo fue hablar acerca de lo agridulce de las relaciones de pareja. Unos meses más tarde (1997), el estreno de La tempestad de Shakespeare en el Nuevo Apolo de Madrid le da ocasión a Bieito de volver a hablar sobre su concepto de

${ }^{13}$ Cuando Muñoz Rojas le pregunta qué es para él dirigir una obra de teatro, Bieito contesta: "Es explicar algo al espectador. Siempre algo muy concreto. Me permite expresar también cómo veo el mundo. Un director tiene la obligación de decir cómo ve el mundo: si es sucio, si es limpio". En Ritama Muñoz Rojas, "Creo que en Barcelona...”, El País, 7/ I I/I 996. 
contemporaneidad, comentando que su puesta en escena es "un espectáculo sobre el mundo y el hombre actuales, [...] una de las obras en las que Shakespeare explica mejor la miseria y la grandeza humana. [...] Creo que ha salido un espectáculo radicalmente contemporáneo y actual porque la obra lo es” (Muñoz Rojas, I 997). Igualmente recalca lo que busca de sus actores (un estilo de interpretación creíble y muy violento), trayéndolos de variadas procedencias (actores de reparto y de cabaret, por ejemplo) para que tengan preparación e instrumentos de interpretación muy distintos a la hora de poner sobre el escenario la variedad de sentimientos humanos que están en el texto: el amor y el odio, la esperanza y la amargura, la libertad y la violencia, en un espectáculo que nos ayude a comprender mejor nuestro propio mundo, semejante al de Shakespeare. ${ }^{14}$ En otras ocasiones afirma que Calderón es un contemporáneo como lo es también Shakespeare.

En 2005 lleva a escena Wozzeck de Alban Berg. En ese momento los medios de comunicación están en general más preocupados por la polémica que despiertan los espectáculos de Bieito que por la novedad o lo hallazgos que puedan comportar. Se le achaca que escoge textos para luego hacer sobre ellos una creación prácticamente independiente del original, trayendo a colación espectáculos como La vida es sueño, Hamlet y Macbeth (tan diferentes entre sí a este respecto), o que la plástica de sus puestas en escena está anclada en el sexo, la violencia y la sangre, aunque justamente es eso lo que se empieza a esperar obligadamente del director y, en ocasiones, lo que llena la taquilla de ciertos teatros. En varios momentos Bieito se siente a un tiempo atacado y exigido a este respecto, y lo cierto es que procura poner sobre el escenario lo que le parece que cada obra pide sin escatimar verosi-

${ }^{\mathrm{I}}$ Bieito recalca las semejanzas entre el momento que vivió Shakespeare y la actualidad a estos efectos: "Era un mundo de cambios bruscos, grandes descubrimientos, amoral y sin valores. Igual que el nuestro. Se trata de hacer un espectáculo sincero y apasionado que nos ayude a conocernos y que refleje nuestro propio mundo". En Ritama Muñoz Rojas, "El premiado director Calixto Bieito...", 28/9/1997. 
militud y medios, pero como la violencia no es un recurso habitual sobre los escenarios, ese punto de vista le acarrea detractores y enfrentamientos. Ya le sucedió que su puesta en escena de La ópera de cuatro cuartos de Brecht y Weill (2002), que se representó sin problemas en Barcelona, Salamanca y París cuando, al ser llevada al Festival del Ruhr en 2004, fue censurada en I 5 minutos y, hablada en español, se representó con unos subtítulos en alemán más atentos al texto de Brecht que a la versión de Bieito y Pablo Ley (Comas,

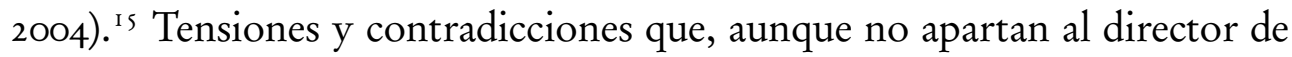
su intención artística, sí le hacen decir "No estoy dispuesto a hacer ópera a cualquier precio". ${ }^{16}$ La provocación y la transgresión "necesaria” que se le pide o se le adjudica sin más le mueven a añadir que

Vivimos en una sociedad tan poco solidaria que la gente intenta destruirse la una a la otra. No hay salida. Afortunadamente no pienso en estas cosas. Cuando cierro la puerta y empiezo los ensayos me aíslo. Me olvido de lo que dicen, de las críticas, de las recriminaciones, de las amenazas y de las posibles broncas. Me concentro en los cantantes y en su trabajo y esto compensa todo lo demás. [...] Yo tampoco soy tan importante. [...] Simplemente hablamos de ópera, un género en el que puedes dar mucho a la gente: una satisfacción, una ilusión, pero en ningún caso tengo la responsabilidad que pueda tener un médico" (Morgades, 2005).

En cuanto a las claves que da para el montaje de Wozzeck, lo ha hecho pensando "en cómo destruimos la naturaleza, en la contaminación del medio ambiente y del cuerpo humano, tanto física como psíquicamente. [...] Es en este sentido en el que la califico de futurista, porque juego a prever

${ }^{15} \mathrm{Al}$ parecer, los derechos de autor están repartidos entre los hijos de Brecht. En Alemania pertenecen a Barbara Schall, que exige un respeto absoluto por el texto, mientras que en otros países son propiedad de otro hijo, más permisivo con los cambios y supresiones. Bieito, muy disgustado por el trato que había recibido pero conmovido por la reacción entusiasta del público (que ovacionó el espectáculo más de ro minutos), zanjó el asunto así: "Digamos que lo ocurrido responde a una falta de sensibilidad artística". En José Comas, "Los herederos de Brecht obligan a Calixto Bieito a cortar La ópera de cuatro cuartos", El País, I/5/2004.

${ }^{16}$ Lourdes Morgades, "No estoy dispuesto a hacer ópera a cualquier precio", El País, $24 / 12 / 2005$. 
lo que sucederá". El director es consciente de que está evolucionando, agradeciendo a Wozzeck el poder ir colocándose en otro lugar y añade que pasa por un momento "romántico", hablando personal y artísticamente. "Me interesa -precisa- salvar la belleza de las cosas. Ser rebelde mentalmente, más reflexivo", lo que en definitiva no es sino ejercer su mirada crítica de otra manera, distinta a la de otros montajes operísticos previos: "La rebelión que he mostrado en montajes como Don Giovanni era furia. A veces uno no hace solo estos cambios, los hace acompañado de obras como Wozzeck" (Morgades, 2005). En este momento hay ya una conciencia generalizada de la innovación que Bieito supone (especialmente para el mundo de la ópera) y de la contemporaneidad que se observa en sus montajes, pero no siempre ha sido así. El propio director, consciente del cambio que puede observarse en su trabajo, no lo oculta pero tampoco lo magnifica, aclarando que la renovación que propone viene más desde el fondo que desde la forma, y afirma:

El cambio en el mundo de la ópera no viene dado por la estética, por usar más o menos pantallas de video u ordenadores, sino por la interpretación de los cantantes de la música y la escena. Por cómo trabajan los conflictos, las tensiones, las situaciones, los puntos de inflexión, el contacto físico. Por cómo el cantante aborda toda esa dramaturgia física” (Morgades, 2005). ${ }^{17}$

Cuando en 2009 lleva Don Carlos de Schiller al escenario, con dramaturgia suya y de Rosich a partir de una traducción de Kovacsisc, Bieito habla de lo que para él supone ser rebelde, que es lo que considera a Schiller, "el

\footnotetext{
${ }^{17}$ En cuanto a su vinculación y respeto al texto original, cuando la entrevistadora le pregunta si ha tenido que alterar el texto original para realizar el viaje escénico que propone, Bieito especifica: "La obra no lo precisa, es perfecta. Solo he tenido que poner la imaginación a su servicio. Es una obra que habla de la explotación y de la alienación humana, y para materializar todo esto no se me ocurriría ambientarla en un contexto militar [...] porque al público actual le dirá muy poco. Había que interpretarla de otra manera sin traicionar su espíritu e incluso el estilo de la época en que fue compuesta la ópera, la de las vanguardias, y aprovechar todo este material para construir este gran universo contaminado. ¿Hacia dónde se encaminan las emociones?, ¿hacia dónde conduce la relación del hombre con la naturaleza?". Lourdes Morgades, "No estoy dispuesto...", 24/1 2/2005.
} 
gran rebelde y reformador", insistiendo en que desde su punto de vista, hoy día en Occidente solo se puede ser rebelde “desde el arte”. Es una puesta en escena a la que Bieito ha llevado los temas que le preocupan, porque cuando hace teatro "las cosas en las que piensa" son asuntos como la gran "modernidad" que se desprende de la figura de Felipe II, "el primer gran político de la historia de la humanidad en el sentido maquiavélico, con presiones y altibajos y laxo a la hora de tomar decisiones" (ABC.es, 2009). ${ }^{18}$

En 2014 estrena en la Ópera de Amberes la rusa Lady Macbeth de Mtsensk de Schostakovich y Preis. Su protagonista, Katherina, vive "en un mundo corrupto, apocalíptico, violento, injusto, lleno de crueldad donde el espacio para el amor es reducido" y por todo ello "responde con violencia a la brutalidad con la que el mundo la golpea”, afirma Bieito, en una entrevista concedida a María Tejero para EFE. De la misma manera que argumentaba en 2005 que Wozzeck mostraba su evolución de la furia a la rebeldía, vuelve aquí Bieito a reconocer que en el escenario puede aflorar su propia rebeldía mental, más reflexiva según va ganando en edad, contra "las grandes lacras de la humanidad: la intolerancia, la injusticia social, la manipulación del pensamiento, el egoísmo, la codicia desmedida y la corrupción de la persona en su sentido más amplio". Bieito, expresivo y sincero, no es sin embargo una persona beligerante en la vida diaria sino alguien prudente que, cuando se le pregunta lo que opina de la situación política en España (algo que se repite en varias ocasiones a lo largo del tiempo) argumenta que, al vivir

\footnotetext{
${ }^{18}$ Bieito, sobre lo que el espectáculo es y la visión global que ha querido plasmar en él, afirma: "Es una lectura política sobre el poder, los muertos, las víctimas, las fosas. Además no he obviado la leyenda negra española, que es merecida aunque también se haya inventado y exagerado mucho al respecto. A Schiller le interesa la poesía y por eso intenta crear un texto poético, no una obra psicológica de folletín". En ABC.es, "Calixto Bieito se aproxima al Don Carlos de Schiller", i s/o9/2009.
} 
fuera del país no puede hablar bien del tema, pero señala que "España duele y entristece". ${ }^{19}$

El director y guionista Lau Delgado dirige en 2013 "El taller universal. Calixto Bieito", documental que se actualiza en 2016 para su emisión por RTVE en el programa biográfico Imprescindibles, de la $2 .{ }^{20}$ En El taller se nos muestra de manera muy sintética un periodo de unos tres meses en la vida del director: su forma de trabajo, su manera de vivir, su carácter, el punto profesional en el que se encuentra y multitud de opiniones suyas sobre diversos temas, y de otras personas ${ }^{21}$ acerca de él. Delgado destaca que estamos en presencia de un director de escena que es capaz de concebir simultáneamente una multiplicidad de proyectos que desarrolla en paralelo; que es plural, puesto que para hacerlo conjuga diferentes disciplinas y que todo ello lo hace en distintos países y lenguas, adaptándose a compañías y elencos muy diferentes, producto de culturas escénicas diversas también. Y todo ello es

Un reto que Calixto Bieito asume con tranquilidad, consciente de que su oficio es sinónimo de movilidad e intensidad, conceptos que se retroalimentan y que permiten al artista diversificar su capacidad creativa, mostrando una característica esencial del artista contemporáneo: la capacidad de crear de forma múltiple, plural y diversa (Delgado, 20ı6).

Creemos que, más allá de comentarios admirativos, críticos o destructores, lo que se pone de relieve al observar la obra de Bieito es el hecho de que siempre despierta pasión: montaje tras montaje, mantiene lejos a la indiferencia y al aburrimiento.

\footnotetext{
${ }^{19}$ María Tejero/EFE, “Calixto Bieito: "La crudeza está en la realidad diaria que nos rodea", 2/4/2014.

${ }^{2 \circ}$ Lau Delgado (dir.), "El taller universal. Calixto Bieito", en Imprescindibles, RTVE, 24/3/2013. Hemos consultado el dvd on line dentro de la actualización realizada para su emisión el i $5 / 4 / 2016$.

${ }^{2}$ Como Rebeca Ringst, Kate Bassett, Stephan Reineke, Andreas Homoki, Claudio Otelli, Óscar Blanco, Annelte Pullen, Eckhard Weber, Juan Echanove, Marc Rosich y Daniel Martínez de Obregón.
} 


\section{¿Director polémico? La gestión de la violencia}

Vemos que Bieito trata una enorme variedad de asuntos a través de sus puestas en escena, sin hurtar en ellas al espectador la crudeza de la palabra o de la plástica puesto que simplemente, él encuentra en la realidad diaria que nos rodea esa violencia, sexo y crueldad que aparecen en sus montajes como reflejo de la naturaleza humana. El director, más proclive a la entrevista o a las declaraciones en rueda de prensa, no tiene muchos escritos teóricos, pero precisamente dedica un pequeño artículo a la violencia, ${ }^{22}$ seguramente porque es el flanco desde el que recibe más ataques, y quiere que sus razones se entiendan bien. La naturalidad y precisión con que lo hace le alejan de divismos, alegando siempre a favor de su trabajo que, puesto que constituye su punto de vista, nutrido de ese mundo interior que le sustenta e influido por su educación, sus recuerdos, el cine, la música y sus lecturas, eso es lo que tiene que verse en sus montajes (Tugues, 2004). ${ }^{23}$ Es su opción y es el riesgo al que está expuesto, sabiendo que es cierto que alguno de sus montajes termina chocando al espectador y que sus procedimientos narrativos y estética pudieran herir sensibilidades; Bieito es consciente de ello, pero ni lo fuerza ni lo evita, proponiendo un método de trabajo serio (Perales, 2006). ${ }^{24}$

${ }^{22}$ Calixto Bieito, "La violencia como representación”, El Cultural de Prensa europea del siglo $X X I, 5 / \mathrm{I}_{2} / 2003$.

${ }^{23}$ Sobre si un montaje que para él es una creación puede ser interpretado como una provocación, Bieito afirma: "Es un hecho que no puedo combatir. Digan lo que digan, no puedo perder mi libertad creativa por intentar gustar a aquellos a quienes no gusto. Estoy expuesto a eso". Pep Tugues, "Entrevista a Calixto Bieito", Diumenge de Avui, I 7/ Io/2004, extracto en www.unanocheenlaopera.com

${ }^{24}$ Afirma el director: "Querría gustar a todo el mundo, aunque Platón decía que eso era de necios; quizá es que soy un necio, pero no tengo ni idea de por qué el público está tan dividido ante mi teatro. Hago lo que creo que debo hacer, pero a veces no hace falta menospreciarme tanto. Estudio una obra, pienso cómo llegar al público, cómo traducirla a nuestros días y cómo llevarla a escena. Eso sí, contaminado por otras artes. Creo que hay espacio para todos, para otros espectáculos más “conservadores”, no sé si es apropiado llamarlos así, y para los míos". En Liz Perales, "Dirigir es como un partido de tenis con los actores”, El Cultural.es de El Mundo, 29/6/2006. 
Uno de los investigadores que mejor recogen esta controversia (libertad creativa, trabajo riguroso, querer gustar a los espectadores, utilizar procedimientos narrativos y estéticos radicales y extrañarse del rechazo violento que alguno de sus montajes provoca) es Roberto Herrscher, dándole al lector la oportunidad de que juzgue por sí mismo. El autor contrasta una sinopsis estándar de lo que sería la apertura de Don Giovanni de Mozart, Macbeth de Shakespeare y Un ballo in maschera de Verdi con el comienzo de los respectivos montajes de Bieito: su Don Giovanni de 200 r en el London Coliseum de Gran Bretaña, el Macbeth de 200 r en Salzburgo y el Un ballo in maschera, en el Liceo de Barcelona en 2000. Los procedimientos narrativos y plásticos de Bieito (sobre los que no podemos extendernos aquí) no son desde luego "esperables" para la mayoría del público: podríamos hablar de que Leporello es un fanático del FC Barcelona y doña Ana persigue insaciable a Don Giovanni, de que Lady Macbeth, una joven minifaldera, disfruta explícitamente de su amante Duncan en un ambiente de mafia de países del Este europeo donde corre la droga, y de que Un ballo in maschera recrea el Congreso de los Diputados de Madrid donde un coro de nostálgicos de la dictadura franquista canta y conspira mientras se bajan los pantalones a la vista del público, sentándose en unos retretes colgados del techo. ${ }^{25}$ Bieito ambientó El rapto del serrallo (2004) en un burdel, teniendo en mente la historia de amor que más impacto le causó, la que aparece en la película $E l$ último tango en París (Tugues, 2004). ${ }^{26}$

\footnotetext{
${ }^{25}$ En Roberto Herrscher, El arte de escuchar. Viajes por la música clásica, Barcelona, Universidad de Barcelona, 201 5, pp. 57-59.

${ }^{26}$ Bieito especifica: "Vi la película y rehice el texto. Fue una gran licencia, pero es que el libreto original no dice nada a un público contemporáneo. Ha sido una revolución en Alemania y es una de mis producciones que más quiero". Tugues comenta: "Con Il Trovatore de Verdi, en Alemania, hubo espectadores que vomitaron...”. Y Bieito le contesta: "Muestra la guerra tal y como pienso que es, como me la imagino. ¡La realidad seguro que es peor!” En Pep Tugues, "Entrevista...”.
} 
Todos los críticos resaltan estos y parecidos rasgos en sus distintos montajes porque, si bien los procedimientos formales a los que Bieito llega imaginativamente son muy diferentes espectáculo a espectáculo, la presencia de la sexualidad, la violencia y la sangre es recurrente, recursos siempre tratados con osadía por el director a lo largo de su carrera: una parte de la crítica lo ve como un exceso gratuito, afirmando que en sus espectáculos se repite demasiado (Tugues, 2004). ${ }^{27}$ Bieito dice que no es un monstruo, ni un terrorista escénico, y que muchas veces la violencia que muestra en sus puestas en escena es de los autores y no suya, poniendo el ejemplo de las Comedias bárbaras de Valle Inclán. Definitivamente, afirma el director, "La violencia pertenece a la naturaleza humana, es consustancial a ella" (Bieito, 2003), ${ }^{28}$ y una parte cada vez más numerosa de la crítica se muestra positivamente impresionada por sus montajes (García Garzón, 2009). ${ }^{29}$

Como si en sí mismo contuviera la polémica, Bieito es un hombre tranquilo amante de la vida familiar, que no aguanta verse inmerso en "Una sociedad capitalista con una doble moral, con un radicalismo creciente que

${ }^{27}$ Bieito responde: "No lo comparto en absoluto. Hay mucha más violencia y más sexo en la televisión que en mis espectáculos y ninguno se escandaliza. Pasa igual en el cine y de una manera peor, porque muchas veces es subliminal. El teatro, al ser en vivo, impacta más. Hay muchos clichés estéticos en el mundo del teatro y la ópera que intento romper, porque son de otras épocas. Por mi parte quiero hacer teatro de ahora, que pide concreción y poca abstracción, y eso crea polémica y conflictos de extremos”. En Pep Tugues, "Entrevista...”.

${ }_{28}$ "La violencia es tan fascinante como puede ser la muerte o el amor, está dotada del mismo tipo de misterio. [...] Su representación, más o menos contundente, más o menos realista en los escenarios, responde por encima de todo al intento de reflejar los estados de conducta de la sociedad en que vivimos. [... Podríamos decir que Shakespeare es el autor más violento de todos los tiempos. Shakespeare trata la violencia en su teatro como parte inherente del ser humano, algo que hace con tanta naturalidad como reír, comer o cantar, y evidentemente, más que un efecto moral, lo que Shakespeare pretende es mostrar la condición humana en todas sus dimensiones. Otro tanto podríamos decir de Calderón. Ellos son precisamente los autores que a mi entender mejor han reflejado la violencia implícita en toda sociedad. [...]. Calixto Bieito, "La violencia...", 5/ I 2/2003.

${ }^{29}$ Sobre Don Carlos, por ejemplo: "Un espectáculo controvertido y poderoso con osadías, golpes de efecto que [...] crecen hasta un final que se eleva sobre el resto". En Juan Ignacio García Garzón, "Una familia política”, ABC.es, 25/9/2009. 
no soporto, porque no soporto la violencia” (Perales, 2006) y rechaza especialmente que se le identifique con ella, recordando que el que esté presente en sus montajes no significa que él lo sea de ninguna manera, al igual que puede suceder con las películas de Coppola, Tarantino o Brian de Palma. Carles Canut, uno de los actores que más ha trabajado con él (y que era el Ross de Macbeth) cree que esa oscuridad que reflejan sus montajes se alimenta de sus lecturas y de su imaginación desbordada, y desde luego de todo el cine que ha visto (Herrscher, 2015: 6I). ${ }^{30}$ Sin embargo sí que quiere obtener de sus espectadores una respuesta emocional y visceral sin paliativos, un impacto en el estómago que les deje pegados en sus asientos (Herrscher, 20 I 5: 59-60), ${ }^{31}$ y el recurso de la violencia puede ser uno de los más poderosos para atrapar al público.

El director, además, opina en su artículo que venimos de un siglo, el siglo $\mathrm{XX}$, que ha sido uno de los más violentos vividos por el ser humano, $\mathrm{y}$ que el XXI lleva el camino de superarlo. Sobre si es obligación del teatro, o de una parte de los espectáculos teatrales al menos reflejar nuestras preocupaciones, dice que "el teatro no ha reflejado al ciento por ciento, tal y como debería hacerlo, la importancia de la cultura de la violencia en nuestras vidas [...] y, sin duda, en lo que respecta a la escenificación de la violencia, ese compromiso por parte de la escena todavía está pendiente”. Bieito opina que hacerlo no es fácil, porque el teatro no tiene las facilidades del cine o de la televisión para llegar al hiperrealismo, pero los actores pueden "llegar a cotas de realidad muy elevadas" en determinados momentos, y también dirección de escena puede elegir dejarse contaminar de otras artes para re-

30"Para Macbeth quiso que todos viéramos las de Tarantino". En Roberto Herrscher, El arte de escuchar..., p. $6 \mathrm{I}$.

${ }^{3}$ Efectivamente, en una potente declaración de principios, Bieito le dice a Herrscher: "Quiero hacer un arte vivo: lo que busco es sacudir el estómago de los espectadores, y desde allí provocar la imaginación y la reflexión. Mis espectáculos son muy directos, muy emocionales, muy melancólicos y muy viscerales. Quiero que el público no se pueda desenganchar de su asiento". Roberto Herrscher, El arte de escuchar..., pp. 59-60. 
mover al teatro de un estancamiento de mucho tiempo, apegado a sus leyes fijas (Bieito, 2003).

En este aspecto y en otros, que tienen que ver siempre con el horizonte del ser humano, las conclusiones de Bieito muestran un punto de vista pesimista pero lúcido: no deja de ver las escasas posibilidades del hombre para escaparse de la corrupción, la crueldad, la violencia y la injusticia, pero su punto de vista no es escéptico ni negativo, siempre es moral y su postura es de denuncia.

Referentes en la plástica de sus montajes: lo español, el cine y los elementos simbólicos.

Bieito parte siempre de una premisa en sus puestas en escena, la intensa y necesaria intersección de dos aspectos: la plástica y el tratamiento de los textos originales, ocupándose él de ambos en muchos montajes. Insiste en que un creador, para dirigirse a los espectadores contemporáneos ha de presentar en sus espectáculos cosas nuevas, pero que al mismo tiempo es vital mantener la esencia de la obra, de un modo que, según va pasando el tiempo, evoluciona junto con el director. En distintas entrevistas ${ }^{32}$ habla de las influencias de orden visual y emocional presentes habitualmente en sus montajes, mencionando como una constante de su trabajo el partir de sus recuerdos para construir sus puestas en escena, porque seguramente los recuerdos son la verdad de cada uno (Zubieta, 200r: 97), ${ }^{33}$ y dentro de ellos alude siempre a la Castilla de su infancia, a las vivencias que le han transmitido sus padres, al cine de Buñuel y a lo "español”, como vamos a ir viendo. Cuando en 2002 habla con Herrscher, el entrevistador (curioso como todos por el origen de ese mundo suyo que podemos ver en el escenario) le

${ }^{32}$ Tan distantes en el tiempo como una entrevista del 2013 (Susana Gaviña) y otra del 200 I (Mar Zubieta).

${ }^{33}$ 'Empiezo ahora a ser consciente de que construyo espectáculos con recuerdos. Como dice Valle Inclán, los recuerdos son verdad. Mis espectáculos están llenos de imágenes de mi infancia y mi adolescencia”. En Mar Zubieta, "Entrevista...", 200 I. 
pregunta por ello, y Bieito responde aludiendo a su capacidad imaginativa y a su sentido del humor, generados en su infancia y primera juventud en contacto con los estímulos, positivos y negativos, que la vida le fue deparando. ${ }^{34}$ Más tarde, la lectura de autores que le acompañaron siempre, como Quevedo, Cervantes y Valle Inclán fue desenvolviendo ese humor negro al que hace referencia, junto a una visión surrealista de la vida que le acerca a Goya, en cuyas Pinturas negras el director ve un anticipo del Expresionismo. Igualmente se declara influido por Velázquez, Zurbarán y Picasso, cuya exploración de Las meninas Bieito pone como ejemplo de lo lejos que se puede llegar artísticamente con la práctica de la deconstrucción (Herrscher, 20 I 5: 6I).

Notable es el peso de estos referentes en su montaje de La vida es sueño (2000), en el que el director firma también la escenografía junto a Carles Pujol, con vestuario de Mercé Paloma e iluminación de Xavier Clot, aunque en Hamlet (2003) la escenografía cobra mayor importancia. Bieito nos muestra un retrato de la decadencia de la monarquía, colocándolo en una escenografía de Ariane Isabell Unfried y Rifail Ajdarpasic (con iluminación de Rick Fisherque) que marca dos espacios perfectamente diferenciados y separados por unas gradas. Al fondo se lee "Palace" en un luminoso, y en la parte delantera está dispuesto un bar privado con sillones tapizados en cuero negro, una mesa llena de botellas y un piano, describiendo un ambiente de "lujo" de los ochenta. Acentuar el peso de lo escenográfico en sus montajes marcará precisamente un nuevo equilibrio entre texto y plástica y un paso elegido por Bieito en su evolución como director de tal forma que,

34"Creo que un poco viene de los cuentos y las historias que me acompañan desde siempre. A mí me afectaron mucho los cuentos infantiles, especialmente los de los hermanos Grimm, La bella durmiente me horrorizaba. Y la versión real, no edulcorada, que leí ya de grande, mucho más. Después el ambiente de mi colegio, con los jesuitas, era bastante violento. Los curas nos daban unas palizas demenciales. A mí me pegaron bastante. Más que traumas me trajo este humor, que es un humor bastante negro". En Roberto Herrscher, El arte de escuchar..., p. $6 \mathrm{I}$. 
al hablar de Tirant lo Blanc (2008), el director propone una escenografía tan poderosa (de Alfons Flores, con vestuario de Mercé Paloma e iluminación de Xavier Clot) que fue acusado por algún crítico de haber dejado el texto en un segundo plano. A ello contesta Bieito afirmando que "Ya ha pasado la etapa en que todo es texto. Un espectáculo es muchas más cosas. El autor y el escritor es una parte más" (Díaz, 2008). ${ }^{35}$ Efectivamente el espectáculo contenía una escenografía grandiosa, una fiesta mediterránea llena de luz como la llamaba Bieito, que enmarcaba en ella el esplendor y la decadencia del ser humano.

Don Carlos (2009) avanza en la misma línea, y fue concebido por Bieito como un poema dramático que, por serlo, permite muchas licencias, traducido por Kovasicks en verso blanco con dramaturgia de Bieito y Rosich. Tiene un lenguaje con predominio de las imágenes y una escenografía de Rebeca Ringst que es un invernadero gigantesco, metáfora de una España que crece espléndida "alimentada por el abono de los millones y millones de muertos que se esconden bajo tierra" (ABC.es, 2009), ${ }^{36}$ un jardín que Felipe II cuida con esmero y en el que viven Carlos de Austria e Isabel de Valois, ambos jóvenes y prisioneros del espacio y de las circunstancias en las que se han encontrado; prisioneros de sí mismos en definitiva. Bieito añade al espectáculo un elocuente subtítulo, Misa pasodoble surrealista, que explica perfectamente la concepción que el director tiene de él: "Misa porque toda liturgia es un gran show; pasodoble porque esta es una música muy española que refleja la vida y la muerte; y surrealista porque es un poema soñado" (ABC.es, 2009).

${ }^{35}$ Carlos Díaz, "Maneras de vivir con Calixto Bieito", Almiar. Margen cero, Revista cultural de lectura rápida (ISSN: 1695-4807), 2008.

${ }^{36}$ ABC.es, Madrid, I 5/9/2009. 
La crítica ${ }^{37}$ señala igualmente un punto en la evolución de las escenografías de los espectáculos del director (García Garzón, 2009) que apunta ya en la dirección del espectáculo total, con marcada influencia de la música, que irá cobrando más importancia en lo teatral y que traduce sobre el escenario la dedicación cada vez mayor de Bieito al mundo de la ópera.

Algo en lo que el director ahonda con el correr del tiempo, puesto que sus espectáculos de ópera son grandes y con escenografías que van teniendo más que ver con instalaciones, según una evolución de la que nos habla él mismo. Por ejemplo, en su versión contemporánea de El gran teatro del mundo (20 I ) junto a Rosich, Bieito, siguiendo las acotaciones del propio Calderón y las indicaciones de un género barroco que desde su origen reclamaba una dimensión operística, ${ }^{38}$ hace una cantata experimental con ayuda de música contemporánea, pidiéndole al compositor Carles Santos música instrumental y arias para ser cantadas durante la representación. Además, el espectáculo tendrá lugar ya en una escenografía-instalación de Rebeca Ringst ${ }^{39}$ que servirá para crear música en directo de mano de los propios actores (Rodríguez Cuadros, 20 I I). ${ }^{40}$ Bieito afirma que Calderón es

${ }^{37}$ Juan Ignacio García Garzón apunta: "Un montaje de gran empaque plástico y erizado de elementos simbólicos: la acción transcurre en un gran invernadero [...] donde la tensión erótica alcanza su temperatura de fusión y la pugna entre libertad de pensamiento y absolutismo político libran su sordo y feroz combate", en "Una familia política”...

${ }^{38}$ Todos los especialistas en los autos sacramentales destacan la importancia que en ellos tenía la música. Alice M. Pollin llega a decir que deberían llamarse "óperas sagradas". En "Calderón de la Barca and Music: Theory and Examples in the Autos (1675-168I)", Hispanic Review 4I, I 973, pp. 367-386.

39 "Una escenografía con grandes tubos metálicos y once actores y cantantes que crean imágenes pictóricas con sus cuerpos”. En La Vanguardia Teatro, Barcelona (EFE), "Bieito transforma El gran teatro del mundo en una cantata contemporánea”, 16/7/20 2.

40 "Los personajes se alinearán sobre un escenario bajo la escenografía-instalación de unas vías de tren y de tubos de órgano - instrumento emblemático del Barroco- creada por la alemana Rebecca Ringst y que serán utilizados por los propios actores para efectos de percusión, abandonando así el uso de una orquestación convencional o del uso de instrumentos musicales antiguos". Evangelina Rodríguez Cuadros, "El gran teatro del mundo; Calixto Bieito vuelve a Calderón”, Blog Ars Theatrica, 3 I/ Io/20 I I. 
uno de sus autores de referencia: "Me trae muchos recuerdos, desde que fui con el colegio a ver su primera obra. Estamos ante una figura que preconizaba la obra de arte total mucho antes que Wagner" (Pérez Martín, 20 2 2). ${ }^{41}$

Bieito tiene conciencia de su evolución como director de escena. Interesado por todo lo que le rodea, los nuevos lenguajes estéticos y medios de expresión le llaman la atención, incorporando a sus montajes novedades significativas que, como ha sucedido siempre, están en función de lo que quiere poner de relieve, de lo que le preocupa, de aquello en que piensa cuando se ve afectado por el estímulo de un texto o un libreto determinado. Y esto es otra constante en su trabajo: sus puestas en escena no son despliegues formales vacíos sino, como hemos ido viendo, se construyen sobre deseos, tensiones y emociones humanas profundas. No obstante el mundo de la ópera, por sus especiales características y con el apoyo de la música, suele ser un buen ámbito para la innovación tecnológica (Monfort, 2009), ${ }^{42}$ contaminación que proviene de otros medios, como el cine o la televisión, pero de la que Bieito se deja llevar de muy buen grado. Pepita Jiménez (2013), por ejemplo, fue una idea que contó inmediatamente con la colaboración del director. En el montaje Bieito vuelve a hablar de sus recuerdos, en este caso de un mundo de sugerencias contenidas en la relación entre erotismo y la represión religiosa en la España de mediados de los 70: "Enseguida supe que iba a ser un espectáculo muy español, cercano a muchos recuerdos. Además, no quería hacer una modernización radical, sino un poema entre el

${ }^{41}$ Miguel Pérez Martín, "Auto sacramental al desnudo", El País, 3/8/20 2.

${ }^{42}$ Le pregunta Montfort: "¿Tanto ha cambiado la mirada del director de escena actual? CB.- Claro. Ha cambiado y en mi caso concreto me alimento de cine, de literatura, de arte contemporáneo, últimamente de instalaciones, de periódicos, de espacios. Me gusta ver cosas nuevas de autores que no conozco. Leer. También, aunque esto no haya aparecido mucho en la prensa española, se suele decir que tengo mucha influencia de Buñuel. Vi de muy pequeño sus películas. Me impresionaron mucho [...] y me quedé con su sentido del humor, que tiene mucho. Se nota que fue a los jesuitas como yo". En Vanessa Montfort, "La ópera es una experiencia física. Calixto Bieito", docenotas.com, 22/7/2009. 
erotismo y la religión, entendida esta como un elemento opresor" (Gaviña, $2013)^{43}$

El director tenía en la memoria la novela de Valera, y cuando se hizo cargo del proyecto le vinieron a la cabeza imágenes de su infancia relacionadas con la España rural y tradicional de antes del 75 , en que erotismo y religión iban de la mano, haciendo posible la represión sexual tan típica de la España de ese momento y que, anclada en la educación, se prolongó durante muchos años. Bieito había entrevisto ese "erotismo de la imaginación" de pequeño en casa de sus tías (Pollini Saldívar, 2012). ${ }^{44}$ Por eso no hay nada en el montaje que nos recuerde a Andalucía, sino más bien a la Castilla de la infancia del director, una España recordada e imaginada en un sentido parecido al que el propio Valera (que renegaba de la España que le tocó vivir) utilizó al escribir su novela, puesto que recreó en su Pepita Jiménez una Andalucía luminosa y soñada, que era la que gustaba de recordar (Gaviña, 2013$)^{45} \mathrm{La}$ propuesta visual que Bieito elabora para el montaje tiene, de nuevo, mucha influencia del cine de Buñuel y en este caso concreto, hace referencia expresa a la película La tía Tula, de Miguel Picazo, de i964. El director bebe estéticamente de ella, intentando transmitir ese aire de opresión de la protagonista, encerrada en un círculo familiar viciado. La escenografía del montaje está inspirada en los armarios roperos de las habitaciones de la infancia (Fernández-Santos, 201 3), ${ }^{46}$ un continente por explorar y en el que

${ }^{43}$ Susana Gaviña, "Calixto Bieito: Existe un erotismo provocado por la religión", $A B C . e s, 21 / 5 / 2013$.

${ }^{44}$ En Margarita Pollini Saldívar, "Entre el sexo y la religión”, estreno de Pepita Jiménez de Calixto Bieito en el Teatro Argentino de La Plata, is/ro/20 2.

45 "En Pepita Jiménez se da ese enfrentamiento entre la religión muy estricta, la que tuvo lugar en los años so en España, y que a mí me han contado mis padres. Con esos recuerdos he hecho un espectáculo un poco vintage. Creo que es muy hermoso estéticamente y muy poderoso por la música. Siendo un paisaje de los años so, puede decir mucho de la España de ahora". En Susana Gaviña, "Calixto Bieito...", 2 I/5/20 3.

46 "Pensé en un elemento que siempre estaba presente en esos recuerdos: los roperos. Allí nos escondíamos de pequeños, y allí parecían estar guardados todos los secretos y recuerdos de las casas. Además, tiene un elemento de cuento, de fantasía, que me interesa, dentro 
escaparse de las exigencias del mundo adulto. Por eso es una enorme pared de 28 huecos, gigantescos en contraste de lo pequeño que puede verse un niño al recordar el ropero en el que se escondía. Un montaje fragmentado, en el que cada puerta que se abre permite el paso de la luz y con ella el inicio de una nueva historia (Pollini Saldívar, 20 2 2). ${ }^{47}$ En él aparece en ocasiones una iconografía católica y en otros momentos banderas españolas de la etapa franquista, pero siempre están esos 28 armarios, todos distintos, que amurallan el escenario, roperos que son un elemento de excepcional teatralidad: ocultan o hacen aparecer a los personajes que, como los niños, escogen esconderse en ellos, jugando, o sufren ser encerrados por los mayores.

Conforme pasa el tiempo, las escenografías operísticas de Bieito, hasta donde hemos podido comprobar, “contienen" más que "arrojan” sobre el patio de butacas lo que sucede en escena. Queda poco del despojamiento, del vacío que era el espíritu de la escenografía de La vida es sueño y de la relación con el público tan especial que había en aquel montaje, puesto que seguramente la música (maravilloso componente de los espectáculos de teatro y esencia de la ópera) distancia algo más que la palabra al espectador de lo que está viendo, y lo coloca muy marcadamente al otro lado de la ficción. ${ }^{48} \mathrm{Y}$ no por ello estamos hablando de escenografías barrocas, puesto que los elementos que Bieto emplea pueden ser simples y polivalentes como ocurre en la del Lear de Reimann (con libreto de Henneberg), ópera de Biei-

ocurren muchas cosas. No sé, como Las crónicas de Narnia...”. En Elsa Fernández-Santos, "Pepita Jiménez sale de 28 armarios", El País Cultura, Io/5/201 3.

47 "La puesta tiene esa estética, y la escenografía es una gran construcción, de nueve metros de altura con una cantidad de antiguos armarios, una locura. Allí aparecen imágenes, me gustan últimamente los espectáculos un poco soñados, y donde una puerta se abre y aparece ahí toda tu historia. En los armarios se ocultan los recuerdos, las frustraciones, los amores, muchas cosas, y así está construida. Es un gran reto para cualquier teatro, no solo para el argentino". En Margarita Pollini Saldívar, "Entre el sexo...”, i 5/Io/20 2.

${ }^{48}$ Aunque en la escenografía de Obabakoak (2017), el último espectáculo dirigido por Bieito para el Arriaga, se podría ver una sencillez que conecta muy bien con la etapa inicial del director. 
to estrenada en la Ópera de París en mayo de 2016. Está inspirada en El rey Lear de Shakespeare (que Bieito montó para el teatro en 2004), la escenografía es de Rebecca Ringst y los elementos son simplemente lamas de madera móviles tratadas con petróleo, quemadas, que durante el espectáculo cobran vida gracias a la luz, de forma que podemos ver en el escenario "paredes de hormigón, después trincheras en el campo de batalla y finalmente el armazón de madera del que se sirven los titiriteros para manejar sus marionetas" (Vicente, 2016). ${ }^{49} \mathrm{Al}$ contrario que en Shakespeare, no hay ya bondad en el anciano rey porque no hay personajes buenos en este espectáculo, y el mensaje es oscuro, pesimista: la familia es el núcleo de esta tragedia que a todos ahoga, donde la responsabilidad es compartida y la escenografía, resto de la grandeza de un palacio desecho y descompuesto, acaba por devorarlo todo.

\section{La música en el universo Bieito}

La música siempre ha estado presente en los montajes de Bieito, $\mathrm{y}$ con cierta frecuencia ha tenido espíritu español: flamenco en La vida es sueño (1 998), pasodoble en Don Carlos (2009), Albéniz en Pepita Jiménez, (2013), por no mencionar Carmen de Bizet (1999), La vida breve de Falla (1999) y las zarzuelas La verbena de la Paloma de Bretón (1997) y El barberillo de Lavapiés de Barbieri (1998). Entre los años 90 y 2010 montó varias óperas, desde luego, pero conforme avanzaba la carrera del director la música en sus puestas en escena adquiría (como la escenografía) más y más protagonismo, empezando a incluir a cantantes en sus espectáculos como sucede con Maika Makovski en Desaparecer (2O I I). De esta manera, y precisamente a partir de 20 I , aunque todavía dirige algún montaje teatral como Camino Real de Tennesee Williams y Forest en 20 г 2, estrena dos montajes muy personales en cuanto a la especial combinación de música y teatro. El primero es Voices (20 I I), con una escenografía poderosa de Rebecca Ringst inspirada en el

${ }^{49}$ Álex Vicente, "Calixto Bieito debuta en la Ópera de París con un Lear contemporáneo”, El País Cultura, 30/5/2016. 
Muro de las Lamentaciones de Jerusalén. Bieito y Marc Rosich escogen una serie de textos sobre el camino de dolor, sufrimiento y culpabilidad que es la vida humana y convierten el montaje en un oratorio barroco con una selección de música y canciones (La Vanguardia, 20 I I $)^{\text {so }}$ que lo convierten en uno de los espectáculos más personales de Bieito. Y el segundo es la puesta en escena de El gran teatro del mundo, de Calderón, estrenada también en 2 OII.

Después su relación con el mundo de la ópera cobra una dimensión de exclusividad, insertándose en una práctica de ciertos directores teatrales españoles que ya había sido iniciada con éxito por Lluis Pasqual (montando Falstaff de Verdi en 1983 y Don Carlo de Verdi en i 985), Nuria Espert (que estrenó Elektra de Strauss en 1989, Carmen de Bizet en 1993 y Turandot de Puccini en 2005) y La Fura dels Baus (con la inacabada Atlántida de Falla y Verdaguer en 1996, El martirio de san Sebastián de Debussy en 1997 y La flauta mágica de Mozart en 2003, entre otros títulos) (Fouce y Saumell, 2007: 37-42). ${ }^{51}$ Además, y en cuanto a su relación con el tratamiento de los clásicos, la puesta en escena de El gran teatro del mundo de Calderón (20 I I), con música de Carles Santos (Sorribes, 20 I I $)^{\text {s2 }}$ llama especialmente la atención. Esta fue la segunda vez que Bieito puso en escena a Calderón y su primera producción dentro de la estructura BIT (Barcelona Internacio-

so“Voices compagina tres estilos de música: canciones de estilo "espectral” en la línea del grupo islandés Sigur Rós; música alternativa con autores como PJ Harvey, Nick Cave, Abba, Tom Waits y Johnny Cash, y música clásica — sobre todo de Johann Sebastian Bachinterpretada por las I 6 niñas que forman el Coro Vivaldi”, afirma Bieito. En La Vanguardia (Europa Press), "Calixto Bieito propone un "via crucis contemporáneo” en su espectáculo Voices”, I 9/6/201 I.

${ }^{5}$ En Héctor Fouce y Mercé Saumell, La música pop y rock y El teatro contemporáneo, Barcelona: UOC, 2007, pp. 37-42.

${ }^{52}$ Con una instrumentación que incluye, "junto a dos harmonios, órgano y percusión, el genial valenciano no duda en usar el sonido de un taladro eléctrico para acompañar la atmósfera de El gran teatro del mundo en su trepidante tránsito del siglo XVII al siglo XXI en manos de un director sin límites". En José Carlos Sorribes, "El gran teatro de Bieito", El Periódico Ocio y Cultura, I I/ I I/20 I I. 
nal Teatre) junto al Theater Freiburg, marcando ese momento a partir del cual el director se vincula más estrechamente al mundo de la ópera. Bieito y Rosich convirtieron el auto sacramental en una cantata experimental, decidiendo que el texto de los personajes mortales fuera recitado por actores alemanes en alemán, mientras que los versos de los personajes alegóricos como el Autor, el Mundo, la Ley de Gracia y el Niño, fueran cantados en castellano, porque "la obra nació en Alemania con actores alemanes", aclara el director en la rueda de prensa con motivo del estreno del montaje en el Teatre Lliure, durante el Festival Grec. Bieito decidió que los textos en alemán se presentaran con subtítulos, aconsejando al público no obstante que "no sigan demasiado el texto" y se concentren en "seguir lo que pasa en escena", porque su intención es llegarles "a través de los sentidos", bien sea con la traducción alemana o con los versos de Calderón, que para Bieito "tienen sonoridades mágicas [...] en una obra que me permite mostrar el tipo de teatro que estoy haciendo, un teatro que se acerca a la poesía e intenta provocar emociones y reflexiones" (La Vanguardia, 20 2 ). ${ }^{53}$ Una interesante declaración de principios con respecto a la adaptación del texto de Calderón, cuya dramaturgia y libreto firman Josef Mackert y Marc Rosich y que conlleva una importante labor de síntesis. Así, aunque se han respetado las líneas fundamentales del texto barroco, se han dejado fuera los momentos más reiterativos, oscuros y difíciles para el espectador contemporáneo, como afirma Rosich (Rodríguez Cuadros, 201 I).

Cuando entrevistamos al director en abril de 2016 le planteamos que una dedicación tan significativa como la suya al mundo de la ópera pudiera deberse a que este sea un buen campo para esas premisas de contemporaneidad, de apertura y de trabajo de los impulsos y del teatro de la energía del que habíamos venido hablando. Él nos contesta que la música es fundamental para su vida sin que la compensación económica tenga peso en ello,

${ }^{53}$ En La Vanguardia Teatro, Barcelona (EFE), "Bieito transforma... 
puesto que sus honorarios son los mismos tanto si dirige ópera como si dirige teatro, y que la música ha pertenecido a su ámbito profesional porque estuvo siempre en su ámbito personal y familiar. Su madre hubiera querido que fuera músico y tiene un hermano que lo es, y quizá la ópera le permite conciliar ambas "vocaciones", música y teatro, avanzando de nuevo en su idea de espectáculo total, porque "en la ópera se juntan todas las disciplinas posibles: la estética, la música, puedes utilizar las nuevas tecnologías (Zubieta, 2016).

\section{Relación entre los clásicos y el mundo contemporáneo.}

Podríamos resumir la forma de trabajar con los clásicos que tiene Bieito diciendo que pretende ser respetuosa y libre al mismo tiempo, estar conectada con la esencia del escritor que pone en escena y al mismo tiempo ofrecer originalidad al espectador. El director ha recibido muchos calificativos que abarcan todo el arco que va desde la aceptación incondicional al rechazo más absoluto, y eso tanto dentro del mundo teatral como en el de la ópera, sin que la línea divisoria entre ambos esté claramente delimitada en un creador que aboga por el espectáculo total, como sabemos. En él pretende orquestar un texto importante, una dramaturgia arriesgada, una interpretación generosa, una escenografía simbólica y potente junto a una iluminación que la haga cobrar vida, un vestuario expresivo y una música elocuente, que señala transiciones y entradas y salidas de los personajes pero también refiere sus conflictos emocionales y es, en ocasiones, un personaje más.

Como hemos ido señalando, la influencia de sus recuerdos de infancia y juventud y la del mundo del cine se nota en sus espectáculos. Bieito lo ha dicho muchas veces y en ocasiones no falta alguna película de culto que el director relaciona con un montaje concreto, como es el caso de Matrix y $\mathrm{La}$ 
vida es sueño. ${ }^{4}$ También hemos visto la intención de Bieito de huir siempre de la afectación, el naturalismo y el costumbrismo en sus trabajos y, en general, su preocupación por el ser humano, su amor por la vida y la importancia que da al marco político de convivencia y a las pulsiones más básicas de la persona (sexo, violencia, crueldad, poder) o más elaboradas socialmente, como el amor y la familia, que están presentes en sus espectáculos frecuentemente. Calixto Bieito define el teatro que hace como "sensorial, abierto e interdisciplinar", construyendolos en profundidad, incluso con un amplio y profundo trabajo previo que puede incluir localización de exteriores (como sucede en las películas), referentes de todo tipo y identificaciones o paralelismos entre el mundo de hoy y su propuesta, en muchas ocasiones a través de la ironía y el humor negro. Que el espectador se sienta aludido, interesado o golpeado siempre está en su propósito, y su mirada, se acerque al texto que se acerque y con cualquier espectáculo que ponga sobre el escenario, es la de un director de escena contemporáneo.

Creemos que podría establecerse, no obstante, una evolución en el tratamiento de los textos originales a los que se acerca, que marcaría una serie de etapas en su trabajo a este respecto. En primer lugar tendríamos montajes en los que muestra una fuerte y explícita vinculación con el original. Es el caso de La verbena de la Paloma, la primera vez que estrena en el Festival de Edimburgo en i 997. En este caso, todas las referencias que hemos visto aluden al libreto de Ricardo de la Vega (adaptado por Albert Mas-Riera) y a la música de Tomás Bretón, aunque Bieito, huyendo de los tópicos casticistas, sitúa la zarzuela en el madrileño barrio de La Latina como hace el original, pero matizado por las analogías del Madrid de finales

${ }^{54}$ Una influencia o contagio que en Bieito podríamos definir en términos de "intermedialidad", entendida por Pavis como la palabra que "designa los intercambios entre los medios de comunicación [...] por ejemplo, un determinado tipo de iluminación cinematográfica puede ser utilizado en teatro...”. En Patrice Pavis, Diccionario del Teatro, Barcelona: Paidós, I 998, p. 25 I. 
del XIX que Baroja muestra en su trilogía La lucha por la vida (Morgades, 1997). 55 También en 1997 estrena La tempestad de Shakespeare, con una traducción de Miquel Desclot que Bieito considera completamente cercana al texto del autor. El director acentúa la comicidad en el montaje y así se subraya en $A B C$, encontrando la puesta en escena innovadora en el lenguaje, con "palabras gordas y giros actualizados" (López Sancho, 1997). ${ }^{56}$

En cuanto a La vida es sueño (Edimburgo, 1998), Bieito firma la versión en castellano (así llama a su intervención en el texto de Calderón), y colabora muy directamente con John Clifford para traducirla al inglés. Versión que hemos visto se ajusta al original con respeto aunque con ciertas particularidades. Sintetizando mucho, podríamos decir que su texto se fija frecuentemente en la edición zaragozana de La vida es sueño aunque circule por la edición madrileña como patrón general, y que una de las formas más peculiares de intervención del director consiste en incorporar al texto en castellano bastantes aportaciones en prosa especialmente en el caso del personaje de Clarín (Boris Ruiz), derivadas con toda probabilidad del proceso de ensayos en Barcelona.

Podríamos ver después una segunda etapa en la evolución de la que hablamos. En ella el director habla de deconstrucción y reconstrucción del clásico que adapta y pone en escena, es decir: muestra también una relación muy directa con el original pero desde una lejanía mayor, siguiendo un proceso de abstracción y de mayor intervención en los textos, en muchos casos con dramaturgias enteramente nuevas o al menos muy diferentes de

"s Afirma Bieito: “Cuando se estrenó, en I 894, todo el mundo sabía que el barrio de La Latina, donde Tomás Bretón y Ricardo de la Vega, el libretista, sitúan la historia, significaba tifus, mierda y gente hacinada en anarquía al filo de la navaja entre la honradez y el puterío. Esta imagen se ha perdido, pero yo he querido recuperarla sin dejar por ello de hacer un espectáculo de contenido moderno". En Lourdes Morgades, "Una Verbena de la Paloma sin tópicos”, El País, i I/8/ I 997.

${ }^{56}$ Lorenzo López Sancho, "La tempestad de William Shakespeare, según Miquel Desclot y Calixto Bieito”, $A B C$, 2/Io/ 997. 
la inicial. Además, en esta etapa aparecen y cobran fuerza las dramaturgias compartidas. Sin ánimo de exhaustividad, pero sí de mostrar un recorrido claro, comenzaríamos esta etapa con Macbeth, estrenado en 200 i en el Festival de Salzburgo con traducción alemana de Frank Günther y actores berlineses. Sobre un texto de Shakespeare que no es fácil, la visión de Bieito despertó posturas encontradas para una de esas lecturas poco convencionales típicas del director. Una parte de la crítica vio ya en el espectáculo (además de una "brillantísima actualización del clásico de Shakespeare") el inicio de un proceso de abstracción en el análisis del texto, conducente a una desmaterialización de Macbeth y a la "conversión en esquema de sus personajes", afirmando que con este montaje Bieito se inserta en "una estética plenamente contemporánea, afín a los lenguajes que han venido transformando la estética teatral en la última década" (Ley, 200 I).57 En la rueda de prensa realizada con motivo del estreno del montaje en Barcelona, y en cuanto a cómo ha trabajado la versión, Bieito afirma que "ha deconstruido el texto", centrado en la destrucción de una familia, trabajando las escenas como si fuera "un puzzle", asegurando que "se mantiene la esencia shakesperiana" aunque "las brujas de Shakespeare se reducen en esta versión a una, Seyton, quien se inspira en la protagonista de Blow up de Michelangelo Antonioni”, destacando la versión catalana de Miquel Desclot (Güell, 2002). ${ }^{88}$ Este montaje se representa en 2003 tanto en catalán como en su versión castellana

57Pablo Ley asiste al estreno en Salzburgo, y resume así sus impresiones: "Aplaudieron la lectura, el enfoque de dirección, porque tal como lo ha concebido Bieito, el espectáculo no da para el lucimiento de los actores. Aplaudieron las referencias, televisivas, cinematográficas. [...]. Aplaudieron el refinamiento, la inteligencia con que las pasiones son convertidas en cancioncillas banales [...] Un público conservador frente a un púbico digamos progresista puede dar una apariencia de polémica que no es más que simple y pura cerrazón. De modo que, en definitiva, fue una polémica sobre el vacío. No hubo, pues, polémica". En "Entre la cerrazón y la entrega", El País, 30/7/200 I.

58 "El texto es poético, pero también fresco y se entiende, por eso quería una versión nueva y de un poeta". En María Güell, "Macbeth es un texto sobre la absurdidad de la violencia", $A B C$.es, 20/2/2002. 
(de la que es autor Bieito junto a Josep Galindo) con subtítulos en inglés en Londres, en el Barbican.

Como vimos más arriba, la deconstrucción es un concepto al que también se refería el director al hablar de la plástica de sus espectáculos; parece que ahora empieza a ser un planteamiento general que extiende al tratamiento de los textos. También observamos que empiezan a intervenir en sus dramaturgias y versiones de sus montajes no ya traductores, sino otros especialistas más cercanos, como Galindo y Desclot. Así, y mientras ha trabajado en Macbeth y lo ha llevado a Londres, Bieito interviene en Homage to Catalonia de Orwell, con reparto mixto de actores catalanes e ingleses y un texto adaptado por Pablo Ley en colaboración con John Clifford. Josep Galindo dirigirá el montaje, que se estrenará también en Inglaterra en 2004. Según Bieito será "un espectáculo basado en la visión de Orwell sobre la Guerra Civil, en cómo la vivió", teniendo en cuenta que su mirada tenía la distancia de una persona que no formaba parte de la contienda. Bieito "explica que la aproximación, muy fiel al espíritu de Orwell, permite sin embargo muchas licencias, adelantando que será "un espectáculo de técnica muy audiovisual"” (El País, 2003) 59

Otra escala importante en esta etapa de "deconstrucción” del director es su montaje de Hamlet, estrenado en Edimburgo en 2003 con una compañía inglesa, en la que el protagonista fue George Anton, el mismo actor que hizo el Segismundo de la versión inglesa de La vida es sueño. En Hamlet Bieito vuelve a trabajar el texto como lo hizo con Macbeth, al modo en que el chef Ferrán Adriá podía deconstruir en El Bulli un plato de cocina tradicional aislando sus ingredientes para presentarlo a sus comensales quizá con un sabor acentuado, pero con una factura y un aspecto totalmente distintos. Bieito centra el peso del espectáculo en torno a cualquiera de las familias reales contemporáneas, explicando que es "una obra sobre la corrupción

\footnotetext{
${ }^{59}$ El País, Barcelona, 2/4/2003.
} 
humana y política, y también sobre la corrupción física" (El mundo.es-EFE, 2003)..$^{60} \mathrm{El}$ director observa muchos puntos de coincidencia entre Hamlet y Macbeth y es consciente de que las importantes intervenciones que ha ejercido sobre el texto (reduciendo el tiempo de representación a dos horas con solo nueve personajes) pueden no ser entendidas por todo el mundo, aunque él cree que la esencia del texto de Shakespeare está también en su Hamlet. Pero le preocupa. En una entrevista que hace antes del estreno en Edimburgo, exclama "Im not a monster!", insistiendo en que el tipo de trabajo que ha hecho en este montaje es semejante al de Akira Kurosawa en su película Trono de sangre, (1957) donde el espíritu del Macbeth de Shakespeare está absolutamente, pero no todas sus palabras (Fisher, 2003). ${ }^{61}$

Otros textos y otros montajes relevantes continúan esta línea de aproximación a los clásicos, y el trabajo con otros colaboradores y dramaturgos en el área textual empieza a ser notable. En La ópera de cuatro cuartos (2002), es Josep Galindo quien interviene en las letras de las canciones y Pablo Ley el que hace la versión castellana del texto. El espectáculo se presentó ante los espectadores germano-hablantes en castellano con subtítulos en alemán. La Celestina, sin embargo, solo se hizo en inglés en el Festival de Edimburgo en 2004, y Bieito ambientó el montaje en un garito de un descampado en mitad de ninguna parte dedicado, claro es, a la prostitución y la droga, con ritmo de rumba a todo volumen. Recurrió a referentes españoles "tópicos" y dividió a la crítica: unos alabaron el que se hiciera accesible en inglés un clásico desconocido para la audiencia de Edimburgo y otros cri-

\footnotetext{
${ }^{60}$ Así lo explica en la rueda de prensa previa al estreno, insistiendo en que "Está toda la esencia de la obra, pero he hecho una reducción, y para ello he aplicado el mismo sistema de Macbeth: he hecho una reconstrucción de la pieza. [...] Habrá algunos que vendrán y me dirán que esto no es Shakespeare, esto no es Hamlet", En El mundo.es, (EFE), "Calixto Bieito estrena Hamlet en el Festival de Edimburgo", 2 I / 8/ 2003.

${ }^{61}$ "He cites as an example of this kind of work Akira Kurosawas film of Macbeth. "It is completely Macbeth but not necessarily all of the words". Bieitos two-hour Hamlet similarly retains the spirit of Shakespeare while coming in at only about half of the length of a full production". En Philip Fisher, "Im not a monster!", British Teatre Guide, 2003.
} 
ticaron el que el director hubiera destruido una vez más una obra maestra de la literatura dramática. Bieito, apodado por cierta prensa británica "el Quentin Tarantino” de las artes escénicas, insiste en que su producción es "una Celestina pura en el sentido de que está llena de referencias a la cultura y el humor negro españoles" (El mundo.es, 2004). ${ }^{62}$ En El rey Lear, también de 2004, Josep Galindo hizo la adjuntía a dirección, la traducción de Shakespeare fue de Joan Sellent y la dramaturgia de Xabier Zuber. En ese mismo año estrena una ópera, El rapto del serrallo de Mozart con libreto en alemán de Gottlieb Stephanie, quien se inspiró en o adaptó otro libreto previo de Christoph Friedrich Bretzner. Siendo uno de los montajes que más aprecia su director, en este caso renueva el libreto entero, porque le pareció que no estaba a la altura de la música de Mozart y que no iba a ser significativo para el público de hoy (Tugues, 2004). ${ }^{63}$

En 2006 estrenó Peer Gynt de Ibsen en Bergen (Noruega) resultando un auténtico éxito. Estaba traducida por Joan Sellent y Anne-Lise Cloetta y contenía modificaciones importantes, como la severa condensación de un relato que en la escritura de Ibsen duraría unas cinco horas. La crítica alude a un "notable respeto por el texto" (Fondevila, 2006), algo que es opinable como en otros montajes del director. ${ }^{64}$

${ }^{62}$ El mundo.es (EFE), "Calixto Bieito lleva La Celestina a un "tugurio de carretera"”, I $7 / 8 / 2004$.

${ }^{63}$ Bieito aclara: "He hecho una versión muy libre. No he tenido ninguna piedad con el libreto porque pienso que es malo. No está a la altura de la música de Mozart y hacía falta uno nuevo. Es una historia de amor y la historia de amor que más me ha impactado ha sido El último tango en París. Vi la película y rehice el texto. Fue una gran licencia, pero es que el libreto original no dice nada a un público contemporáneo”. En Pep Tugues, “Entrevista... (v. nota 23).

${ }_{64}$ "En la primera fila, la gente se envuelve en toallas de rizo para no mancharse de sangre ni vómitos. En el escenario hablan -durante tres horas largas- un idioma que no entendemos. Y adoramos cada segundo. Así se expresaba el crítico del diario VG de Bergen que titulaba: “ ¡S'́ amamos a Peer!”, tras el estreno mundial en Bergen, el pasado 27 de mayo, de la versión de Calixto Bieito sobre la obra de Henrik Ibsen. "Gynt, sadomasoquismo y caos”, tituló el Aftenposten. “Lo más fiel a Ibsen en mucho tiempo?”, se preguntaba el crítico del Bergens Tidende”. [...] Bieito no renuncia a contar la historia, pero lógicamente lo hace a 
Seguiría después, también en 2006, la puesta en escena de la novela de Houllebecq Plataforma, donde Bieito y Marc Rosich hicieron la traducción y la dramaturgia, estrenada en Edimburgo en castellano ${ }^{65}$ y luego en Barcelona y Madrid, anunciando una tercera etapa en la evolución del director, el collage. Las diferentes reseñas de las ruedas de prensa que plasman las opiniones de Bieito con respecto al espectáculo hacen referencia de nuevo a un fenómeno de deconstrucción en la línea que venimos comentando y creemos que el director avanza ahora un paso más allá, puesto que ahora se origina una entidad textual diferente de aquella en la que el espectáculo se originó. En el caso de Plataforma, la adaptación de Bieito y Rosich recrea partes de la novela, añadiendo "poemas y personajes de otras novelas" (hasta donde hemos podido averiguar de Houllebecq también), inaugurando una técnica que el director no duda en llamar "collage". Bieito emplea un sistema narrativo "no lineal, porque si no es muy difícil acceder a un público acostumbrado al cine y a las videoconsolas", para contar una historia de amor que tiene como fondo el turismo sexual de Occidente en los países asiáticos, entendido y criticado como una forma más de explotación de los seres humanos por parte del capitalismo salvaje (El Confidencial, 2006). ${ }^{66}$

En 2007 Bieito, de nuevo acompañado de Marc Rosich, decide hacer una dramaturgia con la que poder llevar a escena un espectáculo complicado por su extensión y su temática y que recorre todo el arco de la literatura medieval catalana. Se trata de Tirant lo Blanc, de Joan Martorell. El direc-

su manera. "Esta obra es una mirada ácida sobre el provincianismo y sus límites, sobre la batalla entre nuestras bondades y nuestras pasiones más escondidas, entre la profundidad del hombre y el animal que lleva dentro", explica el director", En Santiago Fondevila, "Un Peer Gynt pasado por la estética de Bieito en el Teatre Grec", La Vanguardia, 2/7/2006.

${ }^{65}$ El protagonista, Juan Echanove, fue galardonado con el premio Harald Archangel al Mejor Actor.

66 "Hemos hecho un collage, aclaró el director del Teatro Romea y responsable de polémicas puestas en escena, quien no ocultó los temores que le causaba adaptar esta novela”. En El Confidencial, "Houellbecq en estado puro en Madrid con la "Plataforma" de Calixto Bieito y Juan Echanove”, I 2/ I 2/ 2006. 
tor, seducido por la genialidad del autor, crea una fiesta mediterránea para los sentidos en un proyecto extraordinariamente ambicioso, puesto que el original (en la edición crítica de Martín de Riquer que ha servido a los dramaturgos como punto de partida) tiene más de mil doscientas páginas (Departamento Prensa Teatre Romea, Dossier Tirant lo Blanc, 2008) ${ }^{67}$ Aparecen ya de manera muy relevante los nombres de Bieito y Rosich con una importancia de segundos autores, ya que el espectáculo, tanto o más que del texto original de Martorell, depende de su dramaturgia y de la música de Carles Santos. Han explorado las posibilidades de la lengua arcaica, áspera pero llena de expresividad que emplea el autor, renunciando a actualizarla en términos absolutos y llegando a una convención lingüística intermedia que respeta la sonoridad original al tiempo que permite que el significado llegue más claro al espectador. ${ }^{68}$ Como es lógico, los dramaturgos han trabajado la novela renunciando a muchas cosas, prescindiendo de muchos detalles y de la narrativa que podríamos llamar incidental, es decir, no se detienen a contar todos los detalles de todos los episodios que están en el texto de Martorell, puesto que intentan conseguir que la duración del espectáculo no supere las tres horas y que, al ganar en síntesis y densidad, los personajes queden dibujados con mayor fuerza, dureza y desnudez. ${ }^{69} \mathrm{Al}$ mismo tiempo

${ }^{67}$ Bieito afirma: "He querido buscar toda la esencia festiva del original escrito por el caballero valenciano Joanot Martorell para convertirlo en una gran fiesta teatral; en una celebración del hombre en todo su esplendor pero también en toda su brutalidad y decadencia”. En Departamento de Prensa del Teatre Romea, Dossier de prensa de Tirant lo Blanc, febrero 2008 .

${ }^{6}{ }_{8}$ Como apunta Rosich en el Dossier de Prensa del Teatre Romea.

${ }^{69}$ El Departamento de Prensa del Teatro Romea editó para el estreno un dossier de prensa que proporciona mucha información sobre este montaje, como estos detalles que incluimos aquí. Escriben en él Calixto Bieito una nota como director de escena y Marc Rosich otra nota como dramaturgo. Igualmente está la ficha técnica y artística, una lista de los personajes y los resúmenes profesionales de los integrantes del equipo creativo: Calixto Bieito, Carles Santos (música), la Compañía del Teatro Romea (de la que Bieito era director artístico en ese momento), Alfons Flores (escenógrafo, que ya había participado en 8 montajes teatrales y 4 óperas de Bieito), Mercé Paloma (vestuarista, que también había trabajado ya con Bieito en 17 montajes teatrales, entre ellos La vida es sueño, varias óperas 
Bieito y Rosich cuentan que han creado dos personajes nuevos: el primero es Flor de Caballeria (un nombre tomado del título de otro texto de Martorell), que está siempre presente y sería la esencia misma de las órdenes de caballería tanto en lo referente a la filosofía de batalla como al espíritu religioso que gobernaba a estos caballeros, mitad religiosos mitad soldados, persiguiendo siempre los ideales de la guerra santa. Continuamente cercana al protagonista, funciona como un pensamiento que le ilumina con los ideales caballerescos en cualquier situación, de forma que con ella los espectadores pueden tener cerca uno de los temas fundamentales del montaje. El segundo personaje "inventado" es Eliseu, la organista ciega que, como "narradora omnisciente [...] representa la mirada del lector contemporáneo". Bieito afirma: "Esta mujer es una pieza clave de la obra porque ella se va imaginando el mundo de Tirant...", desenvolviendo en escena un mundo surrealista que tiene mucho de sueño, de onírico (Güell, 2008).7०

Cuando en 2008 dirige Los persas, réquiem por un soldado, vuelve a trabajar la dramaturgia del espectáculo con otro colaborador, Pau Miró. Como en estos momentos las dramaturgias en colaboración son ya una práctica habitual en los espectáculos de Bieito, uno de sus entrevistadores le pregunta sobre el motivo que puede tener para hacerlo así, y Bieito contesta: "Porque es mucho trabajo, y así me contamino de gente más joven que yo” (Díaz, 2008). El espectáculo Los persas está inspirado en el texto de Esquilo, con una dramaturgia realizada entre Miró y Bieito que derivó en una versión libre con fuentes de inspiración muy diversas, siempre con la pretensión de

y La verbena de la Paloma y El barberillo de Lavapiés), Xavier Clot (diseño de iluminación, como en otros muchos montajes de Bieito, incluida La vida es sueño) y Rebecca Ringst (video artista y autora de instalaciones, adjunta a escenografía y luego escenógrafa de otros montajes y sobre todo de muchas óperas de Bieito).

70"Y por último reconoce abiertamente que se ha inspirado mucho en Dalí y que por eso [el espectáculo] tiene un punto surrealista, un punto de delirio...”. En María Güell, "Calixto Bieito dramatiza el Tirant lo Blanc en el Romea tras su paso por Frankfurt, Berlín, Madrid”, $A B$ C.es, I 2/2/2008. 
mostrar "cómo la guerra saca lo peor de cada uno y el dolor que produce la pérdida de un ser querido." (La Región, 2007). ${ }^{71}$ En este caso Bieito comenta que ideó la escenografía junto a Alfons Flores, con unos parámetros (no unos resultados) que nos recuerdan a los que tuvo en cuenta en La vida es sueño (La Región, 2007). ${ }^{72}$

En 2009 Rosich colabora de nuevo con Bieito en otra dramaturgia compleja: Don Carlos, sobre el texto de Schiller traducido en verso blanco por Kovacsics, trabajo en el que ya nos hemos detenido en el apartado de este artículo dedicado a la relación del director con la plástica de sus espectáculos. En 20 i Bieito estrena Desaparecer, un espectáculo sobre textos de Edgar Allan Poe, con dramaturgia propia (a partir de la traducción de Julio Cortázar), interpretación de Juan Echanove y la participación de la cantante Maika Makovski, resultando otra manera más de mostrar la importancia que el mundo de la música tiene para el director, algo que va acentuándose, como sabemos. ${ }^{73}$

Desaparecer, que emplea la fórmula de collage ya mencionada, tuvo un largo recorrido por los escenarios, desde el Grec y el Romea hasta los de Venecia, París y Bogotá. Lo mismo sucede con Voices, ${ }^{74}$ también de 20 I I,

\footnotetext{
71 "Tuvimos en cuenta una carta que Freud escribió a Einstein, muchos diarios de militares, el asesoramiento de un soldado que estuvo en Afganistán y hasta un videoclip”. La Región. Cultura. (Agencias), "Calixto Bieito presenta un alegato 'anti la guerra'en la obra Los persas. Réquiem por un soldado”, i s/ i I/ 2007.

${ }^{72}$ Escenografía que Bieito define así: "Queríamos crear el ambiente que queda después de la explosión de una bomba y para ello hemos puesto en el escenario incluso coches quemados de verdad. Por encima de todo, los elementos de la obra están supeditados a mostrar la repulsión y la fascinación por la violencia a través de ún espectáculo muy delicado”', La Región. Cultura. (Agencias), "Calixto Bieito...

${ }^{73} \mathrm{Al}$ igual que vimos en el montaje de El gran teatro del mundo, ya analizado en el apartado de este estudio dedicado a la plástica del director. La música toma ahora mayor protagonismo, no solo porque empieza a hacer muchos más montajes operísticos que teatrales, sino también porque tiene más peso en los montajes de teatro, como hemos ido reseñando.

${ }^{74}$ Sobre Voices ver nota 5o, dentro del apartado dedicado a la importancia de la música para el director en el presente artículo.
} 
igualmente con dramaturgia de Bieito y Rosich. Camino real de Tennessee Williams se estrena en 201 2, en el Teatro Goodman de Chicago. Es un texto elegido por Bieito porque cree que en él Williams intenta apartarse de los usos del teatro del XIX y emplear un lenguaje poético lejos del costumbrismo por el que discurría y sigue discurriendo, a su entender, el teatro que podemos ver habitualmente en los escenarios. La dramaturgia vuelve a ser de Bieito y de Rosich, con quien el director reconoce que trabaja muy bien (López Rejas, 20 I 2). ${ }^{75}$

La idea inicial de su montaje Forests de 20 I 2 fue de una gran sencillez. Bieito había recibido el encargo por parte de London 2012 Festival de poner en escena un texto de Shakespeare, pero aún tenía muy recientes otras puestas en escena del dramaturgo ( $A B C$.es, 20 1 2 $)^{76}$ que había hecho, y cuando se lo propusieron no estaba inclinado a dirigir otra obra del mismo autor. Sin embargo, en una conversación con su mujer la oyó comentar que quería que sus hijos crecieran como árboles, y a partir de ahí el director, gran conocedor de Shakespeare, recordó que en sus textos aparecían árboles, bosques y naturaleza en muchas ocasiones. Releyó su obra desde este punto de vista y consideró que en ella se empleaba la naturaleza para hablar del ser humano, y que podía interesarle hacer un espectáculo sobre esos textos con el tema de los árboles y los bosques como hilo conductor, en la misma clave que estaba empleando para otros montajes suyos de ese momento, donde la parte musical era muy importante y se mezclaban fragmentos de distintos textos

75 'Él quería huir de todo el teatro del siglo XIX. Aún continuamos haciendo teatro del XIX. Todo el West End en Londres y Broodway es teatro del siglo pasado. Él quería escapar de este teatro realista antiguo. Era perfecto para mí”. Y afirma de Rosich: “Trabajo muy bien con él. Quién sabe. Marc es extremadamente inteligente y además no va de genio, ni de 'nueva figura del teatro"'. En Javier López Rejas, "El Rey Lear muestra el vómito contemporáneo. Forest. Camino Real”, El cultural, 24/Io/ $20 \mathrm{I} 2$.

76 "Porque en dos años había dirigido, simultáneamente, Hamlet, Macbeth y El rey Lear en cinco idiomas diferentes, y terminé exhausto". En ABC.es (EFE), "Calixto Bieito estrena en Birmingham Forest”, 4/9/201 2. 
de un mismo autor (www.MADRIDTEATRO.NET, explica sobre Forest en Una mirada al mundo del CDN, 20I 2). ${ }^{77}$

Forest fue una coproducción de BIT y el Birmingham Repertory Theatre Company con la colaboración de la Royal Shakespeare Company dentro de la Olimpiada cultural de Londres 2012. Se estrenó el 4 de septiembre de 2012 en The Old Rep Theatre de Birmingham. Su director lo define como

Un poema sinfónico en tres partes, que finaliza con un epitafio festivo. Es un espectáculo [en el] que, aunque carece de una trama concreta, el público puede identificar emociones, sentimientos, pensamientos, momentos de su vida que pueden verse reflejados en el escenario. [...] Cada árbol es una persona: algunos crecen muy bien, otros se tuercen. Así que pensé, intentemos hacer un espectáculo muy abierto con las palabras de Shakespeare como un poema sinfónico ( $A B C$.es (EFE), 201 2).

En el reparto estuvieron actores catalanes (como José $\mathrm{M}^{\mathrm{a}}$ Pou y Roser Camí) e ingleses (Hayley Carmichael, George Costigan, Christopher Simpsom y Katy Stephens, que provenían de la Royal Shakespeare Company). El montaje estaba hablado en inglés fundamentalmente pero también en catalán, una dificultad que Pou consideraba

Un reto porque no se trata de un inglés coloquial que es el que utilizamos normalmente. Se trata del inglés de Shakespeare, que es más difícil. Agradezco la colaboración de los actores ingleses para ir perfeccionando nuestro inglés. [...] A los ingleses les fascinaba oír a Shakespeare en catalán. (wrwe.MADRIDTEATRO.NET, sobre Forest en Una mirada al mundo del $C D N, 2012)$.

${ }^{77}$ Afirma Rosich: "Existe un vastísimo material y, desde ese aspecto, era fácil encontrar material, pero era difícil seleccionar [...] Hay textos de hasta 20 obras, sonetos y monólogos como La violación de Lucrecia. [... [ [Hicimos] un collage violento quitando tramas originales de la obra y personajes para quedarnos con la sola palabra, ya que la trama como tal no nos importaba. Nos hemos dejado llevar por la música de las palabras. [...] A los textos de las obras elegidas se han añadido sonetos y fragmentos de otras obras poco representadas. [... L La estructura dramatúrgica sigue el esquema de La divina comedia de Dante Alighieri: Infierno, Purgatorio, Paraíso, pero en sentido inverso: Paraíso, Purgatorio e Infierno". En wrww.MADRIDTEATRO.NET, "Forest de Marc Rosich y Calixto Bieito a partir de los bosques de Shakespeare. CDN, Sala Valle Inclán, Una mirada al mundo", $24 / \mathrm{IO} / 2 \mathrm{OI} 2$. 
El proceso de ensayo fue otra de las peculiaridades de este montaje, y muy relacionado con el tratamiento del texto, ya convertido en libreto. Lo vimos en la parte de este estudio dedicada al trabajo de Bieito con los actores, ${ }^{78}$ pero recordemos aquí que ellos no interpretaban personajes sino que decían un texto con varios fragmentos de distintas obras de Shakespeare, siendo además parte de su trabajo encontrar en todo ello un nexo de unión, un hilo conductor que permitiera recorrerlo con significado y con emoción, colaborando con ello a la construcción del espectáculo (wwre.MADRIDTEATRO.NET, sobre Forest en Una mirada al mundo del $C D N, 2012) .{ }^{79}$ Con respecto a la escenografía (creada con el concepto de instalación) y la música, la primera está diseñada por Rebecca Ringst sobre una idea de Bieito, ${ }^{80}$ y la segunda está compuesta por Maika Makovski a partir de canciones y Sonetos de Shakespeare, y se interpreta en directo. Ambas artistas son colaboradoras habituales del director.

Bieito continúa haciendo espectáculos operísticos como Pepita Jiménez (2013), con libreto en inglés, que ya hemos analizado con respecto a su plástica y a la fusión en sus montajes de nuevas tecnologías y medios de expresión. En esta línea tiene muchos proyectos y los presenta continuamente en la escena internacional, produciendo él mismo alguno de ellos, como

78 V. nota I I.

${ }^{79}$ Josep $\mathrm{M}^{\mathrm{a}}$ Pou nos lo refiere con estas palabras: "El espectáculo se complicó con los ensayos, pues nos daban un texto. Te lo aprendías y después se cambiaba. Quiere decir que se fue confeccionando paulatinamente en los ensayos [...] Es que no hay historia o argumento, pero sí situaciones emocionales y estados de ánimo, que es lo que llega al espectador. Aunque no hay historia, nosotros nos hemos inventado una historia que el público no ve". Y Rosich añade: "Aunque no hay personajes sí hay líneas. En lo que respecta al criterio de por qué tal fragmento en inglés o en catalán, nos hemos guiado por aquellas piezas que eran más susceptibles que otras para traducirlas al catalán. Las del catalán son más flexibles para crear piezas de lucimiento". En www.MADRIDTEATRO.NET, "Forest de Marc Rosich...

${ }^{\circ}$ Descrita por José $\mathrm{M}^{\mathrm{a}}$ Pou como "Un cubo con un árbol en lo alto y viene a ser una metáfora para hablar de todo el bosque y, por parte del espectador, se presta a que a partir de esa imagen y de las palabras de Shakespeare pueda imaginar más allá del mismo árbol”. En www.MADRIDTEATRO.NET, "Forest de Marc Rosich... 
sucedió en 2016 con From the House of the Dead para la Staatstheater de Nuremberg, y con Oresteia para el Theater Basel, donde ha realizado también el diseño de vestuario, en 2017.

Por otra parte, después de su nombramiento como director artístico del Teatro Arriaga de Bilbao, ha estrenado en enero de 2017 en esta sala un original proyecto con dos partes, que cuenta con la música del compositor Juan Crisóstomo Arriaga, cuyo aniversario de nacimiento (27 de enero de I 806) quiere Bieito conmemorar todos los años. En este de 2017 su primera propuesta ha sido recuperar la primera ópera del compositor, Los esclavos felices (compuesta con solo i 3 años), y escenificarla desde dos perspectivas durante los días 27 y 28 de enero. El primer proyecto, resuelto con aforo reducido, se representó en dos pases el día 27 y consistió en una performan$c e$, por la que los espectadores fueron paseando por distintas estancias del Teatro Arriaga mientras sonaba música de Arriaga. Pasaban a través de una serie de cubículos donde se estaban proyectando imágenes de Derendiger a modo de "un viaje mental y físico en torno a las condiciones en las que vive el hombre y la mujer actual" (Segovia, 2017) ${ }^{81}$ con la intervención de tres cuartetos de cuerda: Ensemble 442, Bilbao Sinfonietta Cuarteto y Cuarteto La Ritirata. El día 28 se llevó a cabo la segunda parte del proyecto, haciendo en la sala una representación sinfónica y vocal más amplia, interviniendo el coro de la Sociedad Coral de Bilbao, la Orquesta Sinfónica de Bilbao, las sopranos Marta Ubieta y Naroa Intxausti y Markel Murilli (Escolanía Easo).

También en 2017 (pero ya dentro de la temporada I7- I 8 del Arriaga), Bieito ha estrenado Obabakoak, versionando y dirigiendo el texto que mu-

${ }^{8}$ Afirma Bieito, en la rueda de prensa en la que presenta el proyecto. "La producción de Bieito aspira a mover a la reflexión en torno a una cuestión, ¿Somos felices en nuestra esclavitud?”. En Mikel Segovia, “"Los esclavos felices”, de Arriaga, que inspiran a Calixto Bieito”, El Independiente, 25/ I I/ 2017. 
chos consideran el mayor éxito internacional de la narrativa vasca, ${ }^{82}$ obra de Bernardo Atxaga. Un conjunto de historias en que se mezclan realidad y ficción, que no tiene una narrativa lineal y que transcurren en el pueblo de $\mathrm{Obaba}^{83}$ da pie al director para urdir un espectáculo que, bajo una aparente sencillez, reposa en una gran complejidad técnica (Vidales, 2017). ${ }^{84}$ Producción del Arriaga con un equipo de creativos europeo y un reparto de actores vascos, se ha representado en euskera del i 8 al 2 I de octubre y en castellano del 23 al 26 de noviembre y el 2 de diciembre de 20r7, con la intención de llevarla después a Centroeuropa. En 2018 Bieito ha dirigido igualmente Johannes-Passion de Bach, un “oratorio escenificado” coproducido por el Arriaga junto al Châtelet de París, con la presencia de la Orquesta Sinfónica de Bilbao. También dirigirá y presentará en esta temporada un tercer título, The string quartets guide to sex and anxiety, que se representará el 8 y 9 de junio y está inspirado en el ensayo The anatomy of melancholy de Robert Burton, publicado en I62 I, siendo uno de los primeros textos "que abordaron cuestiones relativas a los estados mentales como enfermedades, no solo del individuo, sino de la sociedad, mostrando el psicodrama de la modernidad" (Bilbao.eus, InfoBilbao, Nerws, 2017). ${ }^{85}$ El espectáculo está interpretado en inglés, con sobretítulos en euskera y castellano, y producido por el Birmingham Repertory Theater con la colaboración del Teatro Arriaga.

\footnotetext{
${ }^{82}$ Que ganó en 1989 el Premio Nacional de Narrativa.

${ }^{83}$ Trasunto de Asteasu, pueblo pueblo natal de Atxaga, que tiene que ver con la geografía imaginaria, como Macondo. Montxo Armendáriz, en Obaba, llevó en 2005 la novela al cine.

${ }^{84}$ Sobre su montaje, Bieito afirma: "Soy consciente de que es un texto mítico en Euskadi. Por eso mismo, no me he planteado contentar las expectativas de nadie. Esto es solo una visión parcial, fragmentos de historias que me han conmovido. Es un puzzle, un poema visual, una cantata". En Raquel Vidales, "Obabakoak se reencarna en escena", El País, $25 / \mathrm{IO} / \mathrm{I} 7$.

85 "El teatro Arriaga presenta una temporada 2017-20 I 8 variada, intensa, creativa y estimulante de la mano de Calixto Bieito", en Bilbao.eus, InfoBilbao, Neres, I 4/6/20 7.
} 
Serán los primeros proyectos de otros muchos, esperamos, en Bilbao y por distintas ciudades del mundo, seguramente con el sello personal tan particular que ostentan siempre las creaciones de Calixto Bieito. ¿Se le seguirá considerando un director polémico? ¿Seguirá sintiéndose provocada o amenazada una parte de los espectadores con sus puestas en escena, teatrales u operísticas? Aquí preferimos quedarnos con las palabras de Alberto Miret, uno de los críticos que mejor ha definido esta controversia:

Para algunos son montajes absurdos, ridículos y provocadores por el gusto de provocar; para otros es un director genial y elocuente. [...] La singularidad de Bieito nace de su visión original de las cosas. Tiene su propia estética, identificable en todos sus espectáculos: macarras con cadenas de oro, timadores que fuman marihuana, prostitutas en cabinas telefónicas, violaciones... ¡Y esto sucede en obras de Shakespeare, Calderón o Verdi! Es un artista que se siente libre y que usa su libertad para exigir al público que use su sentido crítico. (Herrscher, 20 I5: 59).

\section{BIBLIOGRAFÍA}

ABC.Es, EP/ Madrid (2009), "Calixto Bieito se aproxima al Don Carlos de Schiller”, I 5/o9/2009.

ABC.ES, EP/ Madrid, (EFE) (2O 2), "Calixto Bieito estrena en Birmingham Forest", 4/9/20 2.

Bieito, Calixto (2003), "La violencia como representación”, El Cultural de Prensa europea del siglo $X X I, 5 / 12 / 2003$.

Bilbao.eus, InfoBilbao, News (2017), "El teatro Arriaga presenta una temporada 2017-2018 variada, intensa, creativa y estimulante de la mano de Calixto Bieito", 14/6/20I7.

Comas, José (2004), "Los herederos de Brecht obligan a Calixto Bieito a cortar "La ópera de cuatro cuartos"”, El País, I 4/5/2004.

Cruz, Alejandro (20 Io), "Un triller filosófico del Siglo de Oro", La Nación, Buenos Aires, i I /7/20 Io.

Delgado, Lau (dir.) (2016), "El taller universal. Calixto Bieito", en Imprescindibles, RTVE, 24/3/20 3. Se actualiza y vuelve a emitir el i $5 / 4 / 2016$.

Departamento de Prensa del Teatre Romea (2008), Dossier de prensa de Tirant lo Blanc, febrero 2008 .

DíAz, Carlos (2008), "Maneras de vivir con Calixto Bieito", Almiar. Margen cero, Revista cultural de lectura rápida (ISSN: 1695-4807).

El Confidencial (2006), "Houellbecq en estado puro en Madrid con la "Plataforma" de Calixto Bieito y Juan Echanove”, I 2/ I 2/2006.

El mundo.es (EFE) (2003), "Calixto Bieito estrena Hamlet en el Festival de Edimburgo", 2 I / 8/ 2003.

El mundo.es (EFE) (2004), "Calixto Bieito lleva La Celestina a un "tugurio de carretera”", 17/8/2004.

El PAís.ES (2003), "Sobre Calixto Bieito”, Barcelona.

Fernández-Santos, Elsa (2013), "Pepita Jiménez sale de 28 armarios", El País Cultura, I07572013. Fisher, Philip (2003), "Im not a monster", British Theatre Guide.

Fondevila, Santiago (2006), "Un Peer Gynt pasado por la estética de Bieito en el Teatre Grec", La Vanguardia, 2/7/2006.

Fouce, Héctor, y Saumell, Mercè (2007), La música pop y rock, y El teatro contemporáneo, Barcelona: UOC. 
García Garzón, Juan Ignacio (2009), "Una familia política”, ABC.es, 25/09/2009.

Gaviñ A, Susana (2013), "Calixto Bieito: Existe un erotismo provocado por la religión", $A B C$.es, $2 \mathrm{I} / 05 / 2013$.

Güell, María (2002), "Macbeth es un texto sobre la absurdidad de la violencia", $A B C$.es, 20/2/2002.

Güell, María (2008), "Calixto Bieito dramatiza el Tirant lo Blanc en el Romea tras su paso por Frankfurt, Berlín, Madrid”, $A B C$.es, I $2 / 2 / 2008$.

Herrscher, Roberto (2015), "Calixto Bieito, sembrador de tempestades", en El arte de escuchar. Viajes por la música clásica, Barcelona: Universidad de Barcelona, pp. 57-68.

LA Región. Cultura. (Agencias) (2007), "Calixto Bieito presenta un alegato 'anti la guerra'en la obra Los persas. Réquiem por un soldado", i 5 / I / 2007.

La Vanguardia (Europa Press) (20 i I), "Calixto Bieito propone un “via crucis contemporáneo” en su espectáculo Voices”, i 9/6/20 I I.

La Vanguardia (Europa Press) (201 2), Teatro, Barcelona (EFE), "Bieito transforma El gran teatro del mundo en una cantata contemporánea", 16/7/201 2.

Ley, Pablo (200I), "Entre la cerrazón y la entrega. Ambiente de polémica en el estreno del Macbeth de Calixto Bieito en Salzburgo", El País.com Cultura, 30/7/200 I.

López Rejas, Javier (2O 2 2), "El Rey Lear muestra el vómito contemporáneo. Forest. Camino Real”, El cultural, 24/10/ 2012.

López Sancho, Lorenzo (1997), “La tempestad de William Shakespeare, según Miquel Desclot y Calixto Bieito", $A B C$, 2/10/ 1997.

Morgades, Lourdes (1997), "Una Verbena de la Paloma sin tópicos", El País, i I/8/ 1997.

Morgades, Lourdes (2005), "No estoy dispuesto a hacer ópera a cualquier precio", entrevista a Calixto Bieito con motivo de su presentación del Wozzeck en el Teatro del Liceo de Barcelona, El País, 24/ I 2/2005.

Monfort, Vanesa (2009), "La ópera es una experiencia física. Calixto Bieito”, docenotas.com, 22/ 7 / 2009.

Muñoz Rojas, Ritama (1996), "Creo que en Barcelona hay más apoyo de las instituciones al teatro". Entrevista a Calixto Bieito, El País, Madrid, 7/ г I/ 1996.

Muñoz Rojas, Ritama (1 997), "El premiado director Calixto Bieito trae su versión de La tempestad de Shakespeare", El País Escena, 28/9/1997.

Pavis, Patrice (2002), Diccionario del teatro, Barcelona: Paidós.

Perales, Liz (2006), "Dirigir es como un partido de tenis con actores", entrevista a Calixto Bieito, El Cultural.es, de El Mundo, 29/6/2006.

Perales, Liz (2009), "Sin arte ni espiritualidad la vida sería muy trivial”, entrevista a Calixto Bieito, El Cultural.es, de El Mundo, 29/5/2009.

Pérez Martín, Miguel (201 2), “Auto sacramental al desnudo”, El País, 3/8/20I 2.

Pollin, Alice M. (1973), "Calderón de la Barca and Music: Theory and Examples in the Autos (1675-168 I”, Hispanic Review 4I, pp. 367-386.

Pollini Saldívar, Margarita (2012), "Entre el sexo y la religión", estreno de Pepita Jiménez de Calixto Bieito en el Teatro Argentino de La Plata, octubre 2012 (Subido por el Teatro de La Plata a su página web).

Que Revienten los artistas, Revista digital de Artes Escénicas (2012), "Marc Rosich nos habla de sus múltiples experiencias como dramaturgo", Año 4, 5/ I 2/20 2.

Rodríguez Cuadros, Evangelina (20 I I), "El gran teatro del mundo: Calixto Bieito vuelve a Calderón”, Blog Ars Theatrica, 3 I/ I / 201 I.

Segovia, Mikel (2017), "Los esclavos felices, de Arriaga, que inspiran a Calixto Bieito", El Independiente, $25 / \mathrm{II} / 2017$.

Sorribes, José Carlos (20 I I), "El gran teatro de Bieito”, El Periódico Ocio y Cultura, I I/ I I/20 I I.

Tejero, María/EFE (20I4), "Calixto Bieito: "La crudeza está en la realidad diaria que nos rodea", 2/4/2014.

Tugues, Pep (2004), "Entrevista a Calixto Bieito", Diumenge de Avui, I7/1o/2004, extracto en www.unanocheenlaopera.com 
Calixto Bieito y los Clásicos: coherencia y evolución de un director de escena 93

Vicente, Álex (2016), “Calixto Bieito debuta en la Ópera de París con un Lear contemporáneo”, El País Cultura, 30/5/2016.

VidAles, Raquel (2017), “Obabakoak se reencarna en escena”, El País, 25/10/2017.

WWW.madridteatro.net (2OI 2) "Forest de Marc Rosich y Calixto Bieito a partir de los bosques de Shakespeare. CDN, Sala Valle Inclán, Una mirada al mundo”, 24/Io/2or 2.

Zubieta, Mar (200 I), "Conversaciones con el director de La vida es sueño, Calixto Bieito", Cuadernos de Teatro Clásico, i s, José M $M^{a}$ Díez Borque (dr.), pp. 97-Ior.

Zubieta, Mar (20 I 5), "Entrevista a Nuria Gallardo, actriz, Rosaura en La vida es sueño", dirección de Calixto Bieito, Madrid, 8/6/2015.

Zubieta, Mar (2016), "Segunda entrevista a Calixto Bieito, director de escena y autor de la versión de La vida es sueño", Bilbao, I4/4/2016.

recibido: enero de 2018

aceptado: febrero de 2018 
